\title{
Cost-Effective Filter Materials Coated with Silver Nanoparticles for the Removal of Pathogenic Bacteria in Groundwater
}

Lizzy Mpenyana-Monyatsi ${ }^{1}$, Nomcebo H. Mthombeni ${ }^{2}$, Maurice S. Onyango ${ }^{2}$ and Maggy N. B. Momba ${ }^{1, *}$

1 Department of Environmental, Water and Earth Sciences, Tshwane University of Technology, Arcadia Campus, Private Bag X680, Pretoria 0001, South Africa; E-Mail: monyatsil@tut.ac.za

2 Department of Chemical Engineering, Tshwane University of Technology, Arcadia Campus, Private Bag X680, Pretoria 0001, South Africa; E-Mails: nomceboH@tut.ac.za (N.H.M.); onyangoms@tut.ac.za (M.S.O.)

* Author to whom correspondence should be addressed; E-Mail: mombamnb@tut.ac.za; Tel.: +27-12-382-6365; Fax: +27-12-382-6354.

Received: 13 December 2011; in revised form: 9 January 2012 / Accepted: 12 January 2012 / Published: 18 January 2012

Abstract: The contamination of groundwater sources by pathogenic bacteria poses a public health concern to communities who depend totally on this water supply. In the present study, potentially low-cost filter materials coated with silver nanoparticles were developed for the disinfection of groundwater. Silver nanoparticles were deposited on zeolite, sand, fibreglass, anion and cation resin substrates in various concentrations $(0.01 \mathrm{mM}, 0.03 \mathrm{mM}, 0.05 \mathrm{mM}$ and $0.1 \mathrm{mM})$ of $\mathrm{AgNO}_{3}$. These substrates were characterised by SEM, EDS, TEM, particle size distribution and XRD analyses. In the first phase, the five substrates coated with various concentrations of $\mathrm{AgNO}_{3}$ were tested against $E$. coli spiked in synthetic water to determine the best loading concentration that could remove pathogenic bacteria completely from test water. The results revealed that all filters were able to decrease the concentration of $E$. coli from synthetic water, with a higher removal efficiency achieved at $0.1 \mathrm{mM}(21-100 \%)$ and a lower efficiency at $0.01 \mathrm{mM}$ (7-50\%) concentrations. The cation resin-silver nanoparticle filter was found to remove this pathogenic bacterium at the highest rate, namely $100 \%$. In the second phase, only the best performing concentration of $0.1 \mathrm{mM}$ was considered and tested against presumptive E. coli, S. typhimurium, S. dysenteriae and $V$. cholerae from groundwater. The results revealed the highest bacteria removal efficiency by the $\mathrm{Ag} /$ cation resin filter with 
complete $(100 \%)$ removal of all targeted bacteria and the lowest by the Ag/zeolite filter with an $8 \%$ to $67 \%$ removal rate. This study therefore suggests that the filter system with $\mathrm{Ag} /$ cation resin substrate can be used as a potential alternative cost-effective filter for the disinfection of groundwater and production of safe drinking water.

Keywords: silver nanoparticles; filter systems; bacterial removal; water disinfection; groundwater

\section{Introduction}

The World Health Organisation (WHO) has indicated that approximately 1.8 million deaths and 61.9 million disability-adjusted life years (DALYs) worldwide are attributable to unsafe water, sanitation and poor hygiene. An estimated $99.8 \%$ of such deaths occur in developing countries, with children ranking (90\%) as the first victims [1]. Consumption of groundwater and surface water sources contaminated with pathogenic bacteria such as Escherichia coli O157:H7, Salmonella typhimurium, Shigella dysenteriae and Vibrio cholera continues to be one the major causes of diarrheal diseases and gastrointestinal infections [2-6]. This implies that safe drinking water plays a significant role in human health and well-being.

In 2002, the United Nation Millennium Development Goals (MDG) firmly established the issue of water and sanitation on the global agenda. The vision of the MDG is to halve the number of people without access to safe drinking water and sanitation by 2015 [7]. Although tremendous progress has been made to date, the 2010 updated report by the WHO and the United Nations Children's Fund (UNICEF) has indicated that 884 million people in the world still lack access to drinking water from improved sources.

The provision of safe drinking water is currently a high priority for the South African government, one of the signatories of the MDG. The percentage of households with access to water infrastructure above or equal to the Reconstruction and Development Programme standard increased from 61.7\% in 1994 to $91.8 \%$ in March 2009. Based on these data, it is estimated that $93 \%$ of the population had access to an improved drinking-water supply in 2010 [8]. In most of the cases, non-improved drinking water supplies are currently found in rural communities that are widely dispersed and informal peri-urban communities that are continuously expanding. It is therefore difficult to implement centralised systems such as piped systems, which not only require substantial financial support, but also highly skilled personnel to manage and maintain them. The implementation of decentralised systems is therefore needed to provide these rural communities with safe drinking-water sources.

Cost-effective filter materials coated with silver nanoparticles is an alternative technology that could assist the developing countries in meeting the MDG, and South Africa, in particular, in providing a safe drinking-water supply to all scatted rural areas and informal settlements. Silver ion $\left(\mathrm{Ag}^{+}\right)$has long been known as a potential antimicrobial agent and is used in wound dressings to prevent infections in burn patients, to blindness in newborns, for severe chronic osteomyelitis and urinary infection, to control Legionella bacteria in hospitals and to improve the performance of drinking-water filters [9-12]. It can bind to bacterial cells and enzymes (proteins) at multiple sites, 
damaging them and preventing them from performing their functions and result, to cells death through penetration at specific bacterial DNA and RNA $[9,13,14]$.

Silver in the form of nanoparticles that release silver ions more effectively has a better bactericidal activity due to its high surface-area-to-volume ratio [15,16]. Recent studies have shown that distinctively prepared silver nanoparticles display good antibacterial activity [17,18]. As a result, researchers have considered silver nanoparticles for drinking-water treatment due to its strong and broad spectrum of antimicrobial activities [19-21]. With the advancement of material development, silver nanoparticles can be easily deposited on solid materials for the deactivation of microorganisms in water treatment [22]. In the case of drinking-water treatment, various forms of silver nanoparticles coated on materials/substrates have been used. These include Ag/sand [23], Ag/zeolite [17] and $\mathrm{Ag} /$ fibreglass [24]. Sand filtrations have been used in water purification to control microbiological contamination for over 150 years [25]. Sand filters are a less expensive, more effective method of water treatment, can be self-constructed and may be constructed by using local skills. Natural zeolites as cation exchangers in water treatment have increased due to their availability, low cost, high surface area and sorptive capacity, negative surface charge, chemical inertness and low or null toxicity for human [26,27]. Most kinds of fibreglass are used for thermal and acoustic insulation in building construction, shipbuilding and filtration applications. Fibreglass-reinforced plastics (FRPs) have been used for various types of process equipment in the chemical industry, pulp and paper industry, power and mining industries, municipal sewer treatment and water treatment, as well as many other associated industries handling corrosive equipment [28]. A number of investigations have been carried out on the use of resins containing silver/silver nanoparticles for oral and dental applications [29,30]. Resins are used in ion exchange and constitute a very powerful technology for removing impurities from water and other solutions. There is no health risk with resins, as many industries use resins for multiple purposes (nuclear and thermal power stations, semiconductors, computers), including dental and pharmaceutical applications and drinking-water treatment for the removal of toxic contaminants [31,32].

Even though a number of studies have been conducted on bacterial removal with $\mathrm{Ag} / \mathrm{zeolite}, \mathrm{Ag} / \mathrm{sand}$, $\mathrm{Ag} /$ fibreglass and $\mathrm{Ag} /$ resin nanoparticle substrates, there is no information on comparative studies related to the use of these technologies for the removal of pathogenic bacteria from drinking-water sources. This study therefore concentrated on the development of these substrates modified with silver nanoparticles and compared their effectiveness in removing pathogenic bacteria (Escherichia coli, Vibrio cholerae, Shigella dysenterae and Salmonella typhimurium) from polluted groundwater sources. Our main intention was to find the alternative cost-effective technology with the best concentration of silver nanoparticles loaded on the substrates, which could completely remove pathogenic bacteria from test water and result in the production of safe drinking water for rural communities.

\section{Experimental Methodology}

\subsection{Preparation of Substrates}

Locally available materials for silver deposition were utilised in the present study. Silver was coated on natural zeolite, sand, fibreglass, anion resin and cation resin. Natural clinoptilolite zeolite purchased 
from Ajax Industries CC (Cape Town, South Africa) was conditioned in a $500 \mathrm{~mL}$ solution of $2 \mathrm{M}$ $\mathrm{NaCl}$ (Merck, South Africa), followed by stirring at room temperature (between 20 and $25{ }^{\circ} \mathrm{C}$ ) for $36 \mathrm{~h}$. The solid-liquid mixture was separated by centrifugation at 3,000 rpm for $15 \mathrm{~min}$. Liquids were discarded and the solids were washed with deionised water three times, and then oven dried at $105{ }^{\circ} \mathrm{C}$ for $8 \mathrm{~h}$. Silica sand purchased from Eggo Sand (Pty) Ltd (Pretoria, South Africa) was submitted to a cleaning process by stirring $200 \mathrm{~g}$ of sand in a litre of $30 \%$ nitric acid (Merck, South Africa) solution with a reciprocating shaker at $210 \mathrm{rpm}$ at room temperature for $24 \mathrm{~h}$. The sand was allowed to settle and separated from the solution by decantation, and thereafter rinsed three times with deionised water and oven dried at $105{ }^{\circ} \mathrm{C}$ for $24 \mathrm{~h}$. Fibreglass chopped-strand mat was purchased from Collins Fibreglass Plastics (Johannesburg, South Africa) and cleaned by immersion in an ultrasonic bath containing isopropanol (Sigma, South Africa) for $2 \mathrm{~h}$. The substrate was rinsed three times with deionised water and oven dried at $105{ }^{\circ} \mathrm{C}$ for $24 \mathrm{~h}$.

\subsection{Synthesis of Silver Nanoparticle-Coated Substrates}

\subsubsection{Coating of Zeolite, Sand and Fibreglass Substrates}

Silver nitrate $\left(\mathrm{AgNO}_{3}\right)$ (Merck, South Africa) stock solution $(1 \mathrm{mM})$ was prepared by adding $169.87 \mathrm{mg}$ of silver nitrate to a litre of deionised water. Thereafter concentrations of $0.01,0.03,0.05$ and $0.1 \mathrm{mM}$ silver nitrate $(250 \mathrm{~mL})$ were prepared by diluting silver stock solution. The substrates $(20 \mathrm{~g})$ were separately immersed in aqueous solution containing concentrations of $0.01,0.03,0.05$ and $0.1 \mathrm{mM}$ silver nitrate for $24 \mathrm{~h}$. They were incubated in a thermostatic shaker at a speed of $250 \mathrm{rpm}$ in the dark at room temperature for $24 \mathrm{~h}$. Substrates containing silver were separated from the mixture by centrifugation at 3,000 rpm for $15 \mathrm{~min}$ and washed with deionised water, and then oven dried for $24 \mathrm{~h}$ at $105^{\circ} \mathrm{C}$. For the reduction of silver ions to silver nanoparticles, the substrates containing silver were heated in an $\mathrm{N}_{2}$ furnace (Lenntech, South Africa) at a flow rate of $400 \mathrm{~mL} / \mathrm{min}$ for $1 \mathrm{~h}$ at $120{ }^{\circ} \mathrm{C}$ and the furnace was ramped up to $350{ }^{\circ} \mathrm{C}$ for $3 \mathrm{~h}$.

\subsubsection{Coating of Anion Resin Beads Substrate}

Amberlite-IRA-458 anion exchange resin (in chloride form) was purchased from Lenntech (Johannesburg, South Africa). Silver was coated on the anion resin beads using the method previously described by [33]. Briefly, the silver nanoparticle-resins were prepared following a two-step procedure. A known amount (20 g) of anion exchange resin was used. Firstly, $30 \mathrm{~mL}$ of $1 \mathrm{M} \mathrm{HCl}$ (Merck, South Africa) solution were added dropwise to $200 \mathrm{~mL}$ stirred, freshly prepared aqueous solution of concentrations of $0.01,0.03,0.05$ and $0.1 \mathrm{mM} \mathrm{AgNO}_{3}$ to form white precipitates of silver chloride. The precipitates were washed three times with deionised water to remove $\mathrm{HNO}_{3}$ and dried in a water bath at $65^{\circ} \mathrm{C}$ for $2 \mathrm{~h}$. The silver precursor $\left[\mathrm{AgCl}_{2}\right]^{-}$complex was prepared by dissolving $0.3 \mathrm{~g}$ of solid $\mathrm{AgCl}$ in a concentrated $\mathrm{HCl}$ solution and the mixture was placed in an ultrasonic bath for dissolution. Secondly, the silver precursor ions were allowed to exchange with $\mathrm{Cl}^{-}$ions of the neat chloride form of anion-exchange resin beads $\left(\mathrm{R}^{+} \mathrm{Cl}^{-}\right)$and the mixture was kept overnight. The resin beads, on which silver precursor ions were immobilised, were washed three times with water to drain out the liberated $\mathrm{HCl}$ and un-exchanged $\left[\mathrm{AgCl}_{2}\right]^{-}$and then reduced with a freshly prepared ice-cold 
aqueous solution of $0.01 \mathrm{M}$ sodium borohydride. The prepared shining reddish-black silver-coated beads $\left[\mathrm{R}(\mathrm{Ag})^{0}\right]^{+} \mathrm{Cl}^{-}$were washed thoroughly with deionised water and dried at room temperature in a vacuum.

\subsubsection{Coating of Cation Resin Beads Substrate}

The methods described by [34] were also used for the coating of cation resin. The silver amine complex, $\left[\mathrm{Ag}\left(\mathrm{NH}_{3}\right)_{2}\right]^{+}$, was prepared by adding $10 \mathrm{~mL}$ of $25 \%$ ammonia solution dropwise to each of $200 \mathrm{~mL}$ aqueous solution of concentrations of $0.01,0.03,0.05$ and $0.1 \mathrm{mM} \mathrm{AgNO}$. A known amount $(20 \mathrm{~g})$ of cation exchange resin $\left(\mathrm{R}^{-} \mathrm{H}^{+}\right)$was added to each of these mixtures, followed by a mixing process for $3 \mathrm{~h}$ using a magnetic stirrer. The resin silver amine moiety $\left[\mathrm{R}-\mathrm{Ag}\left(\mathrm{NH}_{3}\right)_{2}\right]$ was washed three times with deionised water and heated in an oven at $150{ }^{\circ} \mathrm{C}$ for $1 \mathrm{~h}$. The yellow colour of the resin beads was transformed to black due to the formation of resin silver oxide composite $\left[\mathrm{R}\left(\mathrm{Ag}_{2} \mathrm{O}\right)\right]^{-} \mathrm{H}^{+}$. Then, this complex was reduced with an aqueous solution of freshly prepared $0.01 \mathrm{M}$ sodium borohydride to form silver nanoparticle-coated resin beads $\left[\mathrm{R}\left(\mathrm{Ag}^{0}\right)\right]^{-} \mathrm{H}^{+}$, with a white colour. The silver nanoparticle-resin beads were washed three times with deionised water and finally dried on a water bath at $65{ }^{\circ} \mathrm{C}$ for $2 \mathrm{~h}$ to obtain dry silver-coated resin beads.

\subsection{Characterisation of Substrates Coated with Silver Nanoparticles}

The surface morphology of the silver nanoparticles-coated substrates was examined with a scanning electron microscope (SEM) (JEOL JSM-5800LV, JEOL Ltd, Tokyo, Japan) coupled with energydispersive spectroscopy (EDS) to confirm the chemical content on the substrates. Transmission electron microscope (TEM) analysis was performed with a JEOL 2100F (JEOL Ltd, Tokyo, Japan) that operated at $100 \mathrm{kV}$ to examine the morphology and particle size distribution of the silver nanoparticle substrates. X-ray diffraction (XRD) was used to determine the crystal phase of the substrates. The patterns of the silver nanoparticles were recorded with a Bruker D8 Advance using $\mathrm{Cu}$ $\mathrm{K} \alpha$ radiation with $1.5416 \AA$ wavelengths. The structure of the silver on the substrates was studied by scanning the media in $2 \theta$ ranges from 30 to $80{ }^{\circ} \mathrm{C}$ in a continuous scan mode. The crystallite size of the silver substrates was determined from X-ray line broadening using the Debye-Scherrer equation as follows:

$$
D=\frac{K \lambda}{\beta \cos \theta}
$$

where $\mathrm{D}=$ Crystallite size, A (Angstroms), $\mathrm{K}=$ Crystallite-shape factor $=0.9, \lambda=\mathrm{X}$-ray wavelength, $1.5416 \AA$ for $\mathrm{CuK} \alpha, \theta=$ Observed peak angle, degree, $\beta=\mathrm{X}$-ray diffraction broadening, radian.

\subsection{Production of Combined Substrate-Silver Nanoparticle Filter Systems}

The filter systems consisted of a polyvinyl chloride (PVC) column of $2 \mathrm{~cm}$ diameter and $20 \mathrm{~cm}$ length (Figure 1). Each column was packed with one type of the substrate coated with silver nanoparticles at a depth of $10 \mathrm{~cm}$. With reference to various substrates (sand, zeolite, fibreglass, anion resin and cation resin), five filters were used during the study period. Glass beads $(2 \mathrm{~cm})$ and glass wool $(2 \mathrm{~cm})$ were placed in the upper and bottom ends of each column. Glass beads were positioned to 
prevent the substrates from pilling up at one end. A $10 \mathrm{~L}$ bucket served as storage container for contaminated influent water, which was fed into the filter system with a $1 \mathrm{~m}$ length of $8 \mathrm{~mm}$ diameter latex tubing connected to a Rainin Dynamax peristaltic pump (Rainin Instrument Co., Woburn, MA, USA). The effluent sample (treated water) was collected at the top of the filter with a $1 \mathrm{~m}$ length of $8 \mathrm{~mm}$ diameter latex tubing into a $10 \mathrm{~L}$ bucket container. Figure 1 illustrates the schematic diagram of a laboratory-scale setup with an example of a combined substrate-Ag nanoparticle filter system.

Figure 1. Schematic diagram of laboratory-scale setup to evaluate the antibacterial efficiency of Ag nanoparticle-coated substrates.

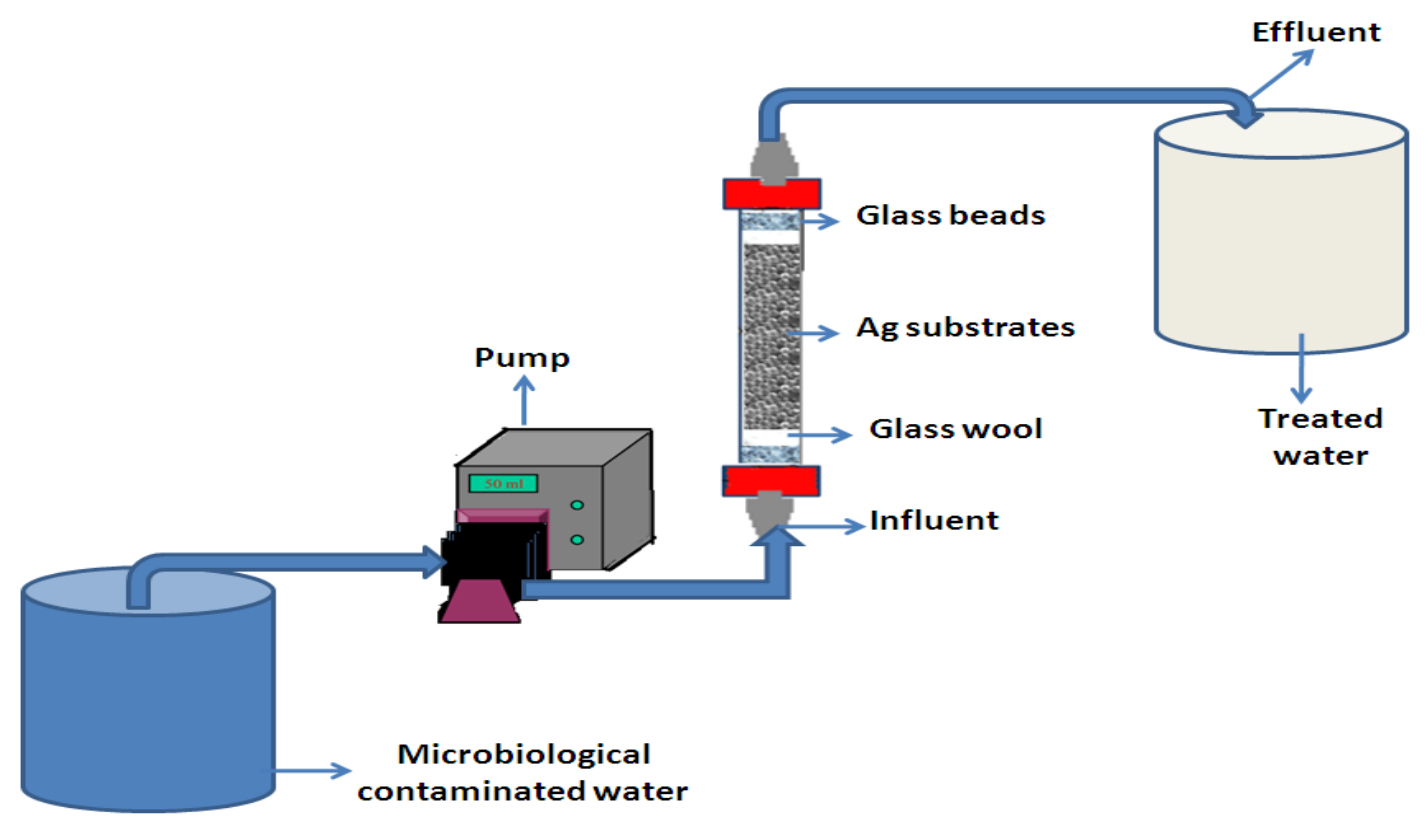

\subsection{Testing the Efficiency of Filter Systems in Removing Pathogenic Bacteria}

The performance of the combined substrates-silver nanoparticle filter systems in removing pathogenic bacteria was studied in two phases. In the first phase, the five substrates coated with various concentrations of $\mathrm{AgNO}_{3}$ were tested against Escherichia coli (ATCC 43895) spiked in synthetic water samples. The main objective of this part of the study was to determine the best loading concentration of $\mathrm{AgNO}_{3}$ that could result in the total removal of pathogenic bacteria from a test water source. In the second phase, the performance of the five combined substrates-silver nanoparticle filter systems was tested using groundwater, and only the best concentration of silver nanoparticles loaded on the substrates was investigated against the four different pathogenic bacteria-E. coli, $S$. typhimurium, $S$. dysenteriae and $V$. cholerae. In cases where these pathogens were not present in the intake groundwater source, the water was spiked with the pathogens. This was mainly done to evaluate the efficiency of each filter in reaching the allowable recommended limits set by the South African National Standards for domestic use [35,36]. The bacterial removal efficiency was obtained by comparing the concentrations $\left(\log _{10} \mathrm{cfu} / 100 \mathrm{~mL}\right)$ of target organisms before and after treatment. In each series of the experimental study, a control filter constituted of the substrate without silver nanoparticles was included. The experimental study for each combined substrates-silver nanoparticle filter system was performed in three different trials. 


\subsubsection{Preparation of Bacterial Stock Suspensions}

The microbial strains used in the experimental study included Escherichia coli (ATCC 43895) and Salmonella typhimurium (ATCC 14028) obtained from the American Type Culture Collection (Rockville, MD, USA), Vibrio cholera and Shigella dysenteriae obtained from the Council for Scientific and Industrial Research (CSIR, Pretoria, South Africa) bacterial stock cultures. Prior to use, these bacterial strains were confirmed by cultural tests using selective agar medium (Chromocult agar for E. coli, XLD agar for S. typhimurium and S. dysenteriae, TCBS agar for $V$. cholera) according to the Standard Method [37]. One loop full of each bacterial culture was separately inoculated in $100 \mathrm{~mL}$ sterile nutrient broth (Merck, South Africa) medium and incubated aerobically at $37{ }^{\circ} \mathrm{C}$ in a shaking incubator (Scientific Model 353, Lasec, South Africa) at $120 \mathrm{rpm}$ for $24 \mathrm{~h}$. The bacteria were harvested by centrifugation at 4,000 rpm for $10 \mathrm{~min}$ and the pellet was washed twice with $50 \mathrm{~mL}$ of sterile $0.01 \mathrm{M}$ phosphate-buffered saline (PBS, pH 7.2).

The stock suspensions of E. coli, $S$. typhimurium, $S$. dysenteriae and $V$. cholera were prepared by re-suspending the final pellets in $10 \mathrm{~mL}$ of $0.01 \mathrm{M}$ PBS solution. The initial concentrations of bacterial cells harvested were determined with the spread-plate technique, after serial dilution of each culture in sterile saline solution $(0.9 \% \mathrm{w} / \mathrm{v} \mathrm{NaCl})$. The plates were incubated at $37{ }^{\circ} \mathrm{C}$ for $24 \mathrm{~h}$. The resulting colonies were counted and expressed as $\mathrm{cfu} / \mathrm{mL}$.

\subsubsection{Preparation of Synthetic Contaminated Water}

For each filter system, an aliquot of the stock suspension of E. coli (ATCC 43895) corresponding to $6 \log \mathrm{cfu} / 100 \mathrm{~mL}$ was inoculated into $10 \mathrm{~L}$ final volumes of sterile saline water $(8.5 \% \mathrm{NaCl})$. The spiked water samples were shaken vigorously several times and $1 \mathrm{~mL}$ of this water source was used to determine the initial concentration of the target organism before passing the remaining contaminated water through the filter systems.

\subsubsection{Collection and Analysis of the Quality of Groundwater Samples}

Groundwater samples were collected from a borehole at Delmas (A7) in the Mpumalanga Province of South Africa. The study was conducted between June and July 2010 and the water samples were collected three times during this period. It is important to note that, during the study period, this groundwater supply was used by the community without prior treatment. The water samples were collected in sterile $50 \mathrm{~L}$ plastic buckets. Samples were also collected in sterile $1 \mathrm{~L}$ glass bottles in order to detect and enumerate the initial concentrations of the target bacteria and selected physicochemical parameters before treatment. The samples were transported to the laboratory and the quality of the water was determined for microbiological contamination and selected physicochemical parameters within $6 \mathrm{~h}$ [37].

Escherichia coli, S. typhimurium, S. dysenteriae and $V$. cholerae were detected and enumerated from groundwater samples according to Standard Methods [37]. As mentioned above, in cases where these organisms were not detected in groundwater samples, they were spiked with $10^{2} \mathrm{cfu} / \mathrm{mL}$ stock suspension in these test water sources using the same method as described for synthetic water samples. All the tests were conducted in aseptic conditions. 
The $\mathrm{pH}$ and the turbidity were measured on site using a $\mathrm{pH}$ meter (Metrohm Co. Model 713) and a microprocessor turbidity meter (Eutech Instrument Turbidimeter TN-100), respectively. Nitrates and fluoride concentrations were determined in the laboratory using the Spectroquant Nova 400 manual water analyser (Merck) and photometric test kits (Merck), while the concentrations of magnesium, calcium in the water sample were determined by atomic absorption spectrophotometry (SpectrAA 220FS), according to Standard Methods [37].

\subsubsection{Operating Conditions and Testing the Performance of the Filter Systems}

Before the start of each run, the packed columns were pumped upward with sterile deionised water to adjust and achieve a steady-state flow condition. Thereafter, each type of test water source contaminated with enteric pathogenic bacteria was pumped continuously through the column in the up-flow mode with a Rainin Dynamax peristaltic pump (Rainin Instrument Co.) that operated at a flow rate of $0.12 \mathrm{~L} / \mathrm{h}$. Treated water samples were collected in sterile conical flasks at 10 -minute intervals at

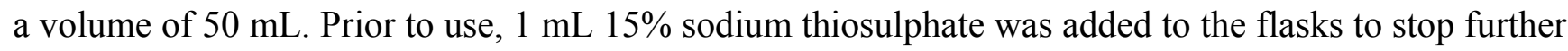
disinfection of drinking water before determining the bacterial concentrations. The bacterial concentrations were determined by serial dilution in sterile saline solution and plated on selective medium by using the spread-plate technique according to Standard Methods [37].

\subsubsection{Elution of Silver Ions from Silver Nanoparticles Substrates Filter Systems}

The degree of elution of silver from each combined substrates-silver nanoparticle filter system used in the first phase with spiked synthetic water was measured. The silver content in the treated water samples was determined with atomic absorption spectroscopy (AAS) by using a Spectra AA-220FFS (Varian Medical Systems, Inc., Palo Alto, CA, USA).

\subsection{Statistical Analysis}

All data were analysed statistically using the SPSS computer software version 11.0. Testing of significance was carried out using the one-way analysis of variance (ANOVA) at a 95\% confidence interval. Comparisons were made between the treatment means of each filter system to determine if there were significant differences in treatments.

\section{Results}

\subsection{Characterisation of Silver Nanoparticles Coated on Substrates}

Figure 2 shows the morphologies and the elemental composition of the silver nanoparticles coated on substrates ( $\mathrm{Ag} /$ zeolite, $\mathrm{Ag} / \mathrm{sand}, \mathrm{Ag} /$ fibreglass, $\mathrm{Ag} /$ anion resin, $\mathrm{Ag} /$ cation resin) examined with SEM micrograph and EDS analyses. The silver nanoparticles were noticed as small white spherical particles on the surface of the sand, fibreglass and anion resin. In cation resin, the silver nanoparticle coating completely covered the resin bead and the film revealed a homogeneous rough surface. The structure of the silver nanoparticles in zeolite was complex due to sample charging. Zeolite sample charging could indicate a low electrical conductivity of the medium even though carbon coating had 
been applied to avoid charging. The EDS spectra also confirmed the elemental composition of silver nanoparticles by the presence of Ag peaks in the synthesised substrates. In the spectra, two peaks of Ag located between $3.0 \mathrm{kV}$ and $3.5 \mathrm{kV}$ were observed in zeolite, four peaks for sand located between $2.5 \mathrm{kV}$ and 3.5, four peaks for fibreglass between $1.0 \mathrm{kV}$ and 4.0, five peaks for anion resin between $2.0 \mathrm{kV}$ and 4.0 and six peaks for cation resin between $1.0 \mathrm{kV}$ and 4.0. The EDS spectra also showed the presence of other major elements found in zeolite ( $\mathrm{Na}, \mathrm{Mg}, \mathrm{Al}, \mathrm{Si}, \mathrm{Ca}, \mathrm{K}, \mathrm{Ti})$, sand (C, Fe, $\mathrm{Al}, \mathrm{Si}$ ), fibreglass $(\mathrm{Al}, \mathrm{Si}, \mathrm{Ca})$, anion resin $(\mathrm{C}, \mathrm{N}, \mathrm{O}, \mathrm{Al}, \mathrm{Cl})$ and cation resin $(\mathrm{C}, \mathrm{O}, \mathrm{Al}, \mathrm{S})$. The carbon and oxygen peaks of the EDS analyses could be due to the carbon tape used for SEM stub preparation.

Figure 2. SEM image and EDS spectrum of (a) zeolite, (b) sand, (c) fibreglass, (d) anion resin, and (e) cation resin coated with silver nanoparticles.
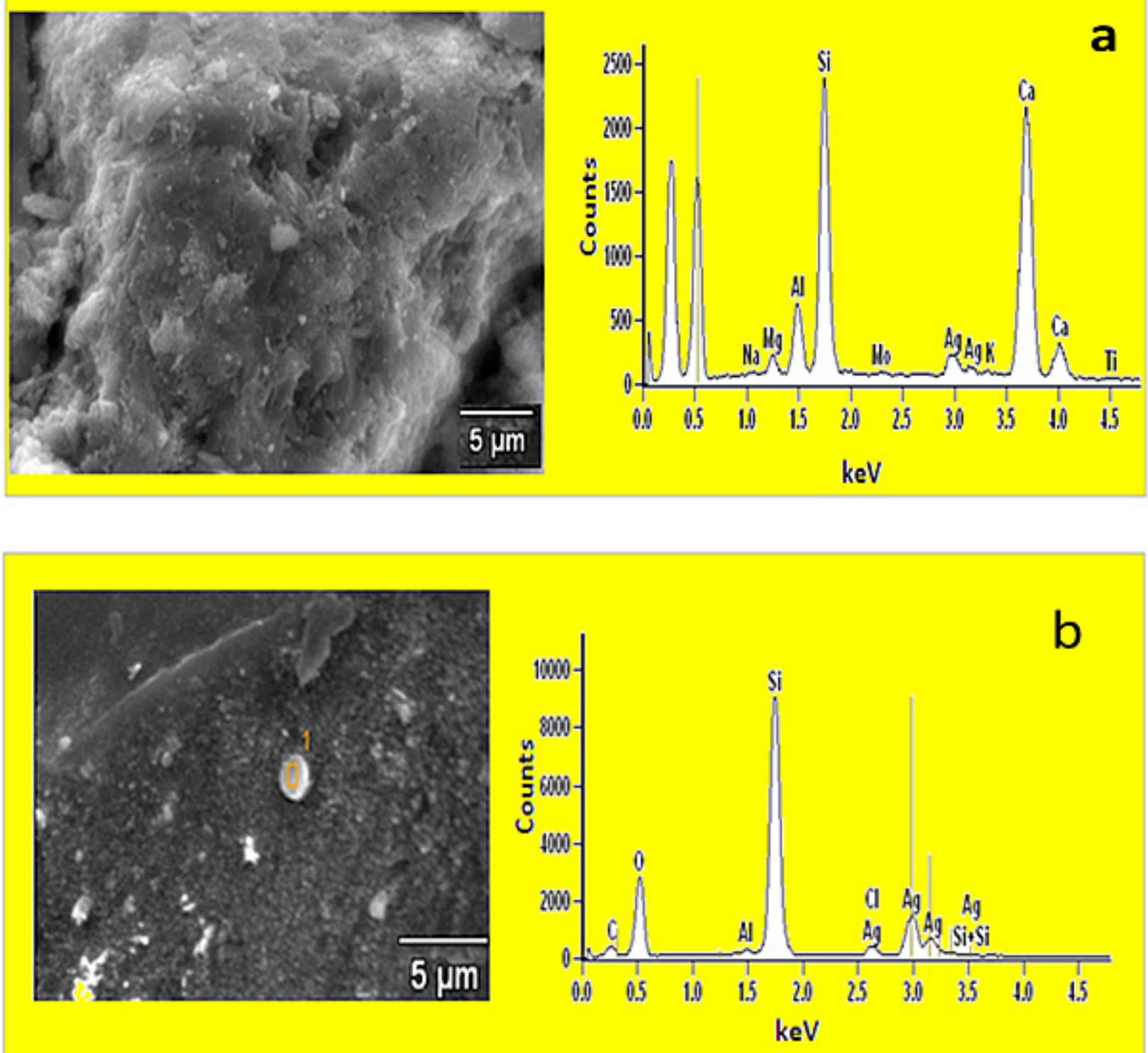
Figure 2. Cont.
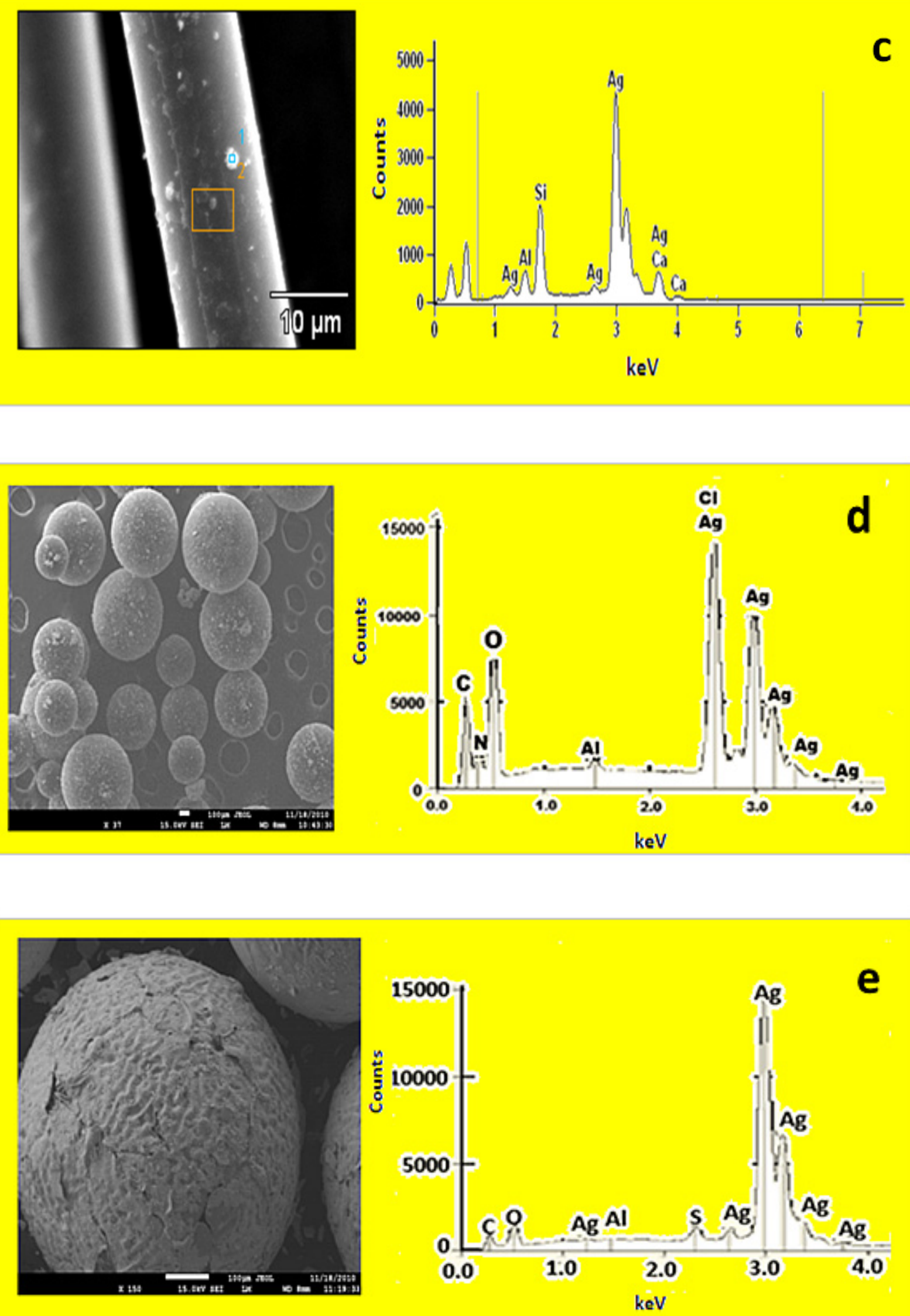
Figure 3 shows the results of the TEM image and particle size distribution histogram of silver nanoparticle substrates (zeolite, sand, fibreglass, anion and cation resin beads). The morphology of silver nanoparticles deposited onto substrates exhibited spherical-shaped particles that aggregate to each other. According to the particle-size distribution histogram, the silver nanoparticles have shown a majority particle sizes distributed from 40 to $90 \mathrm{~nm}$ for zeolite and sand, and 5 to $30 \mathrm{~nm}$ for fibreglass and resin beads.

The diffraction pattern of the synthesised silver nanoparticle substrates shown in Figure 4 matched the face-centered cubic (fcc) structure of silver observed at $2 \theta$ angle $37.7^{\circ}, 44.0^{\circ}, 64.2^{\circ}$ and $77.1^{\circ}$. These corresponded to the four diffraction peaks above $30^{\circ}$ (111), (200), (220) and (311) crystal planes, respectively, clearly indicating that the silver nanoparticles are crystalline in nature. The XRD patterns were analysed to determine the average crystallite size obtained by classical Scherrer equation indicated in Section 2.3.1. The typical XRD pattern estimated average nanocrystallite sizes of $85 \mathrm{~nm}$ for zeolite, $80 \mathrm{~nm}$ for sand, $28 \mathrm{~nm}$ for fibreglass, $20 \mathrm{~nm}$ for anion resin and $13 \mathrm{~nm}$ for cation resin derived from full-width at half-maximum (FWHM) of peak corresponding to 111 plane with cubic shape. The zeolite substrate (Figure 4(a)) did not show any well-defined peaks which indicated an amorphous nature of the sample. All the substrates showed low-intensity peaks of silver at $2 \theta=77.1^{\circ}$. As seen in Figure $4(a-c)$, in addition to the four peaks of the crystal plane, other unidentified peaks also appeared in the XRD pattern.

Figure 3. TEM image and particle size distribution of (a) zeolite, (b) sand, (c) fibreglass, (d) anion resin, and (e) cation resin coated with silver nanoparticles.
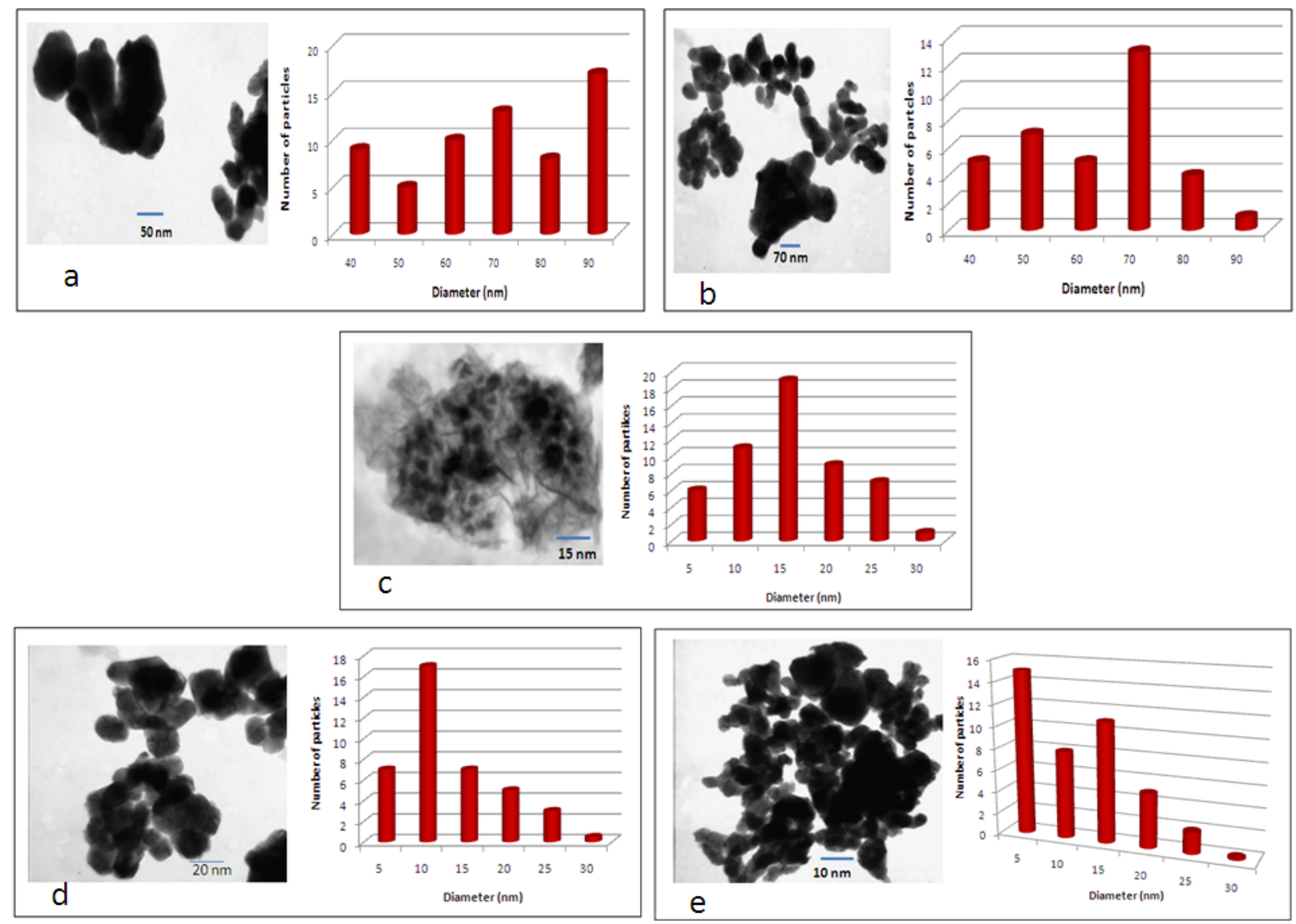
Figure 4. XRD patterns of the silver nanoparticles coated on (a) zeolite, (b) sand, (c) fiberglass, (d) anion resin, and (e) cation resin.

a
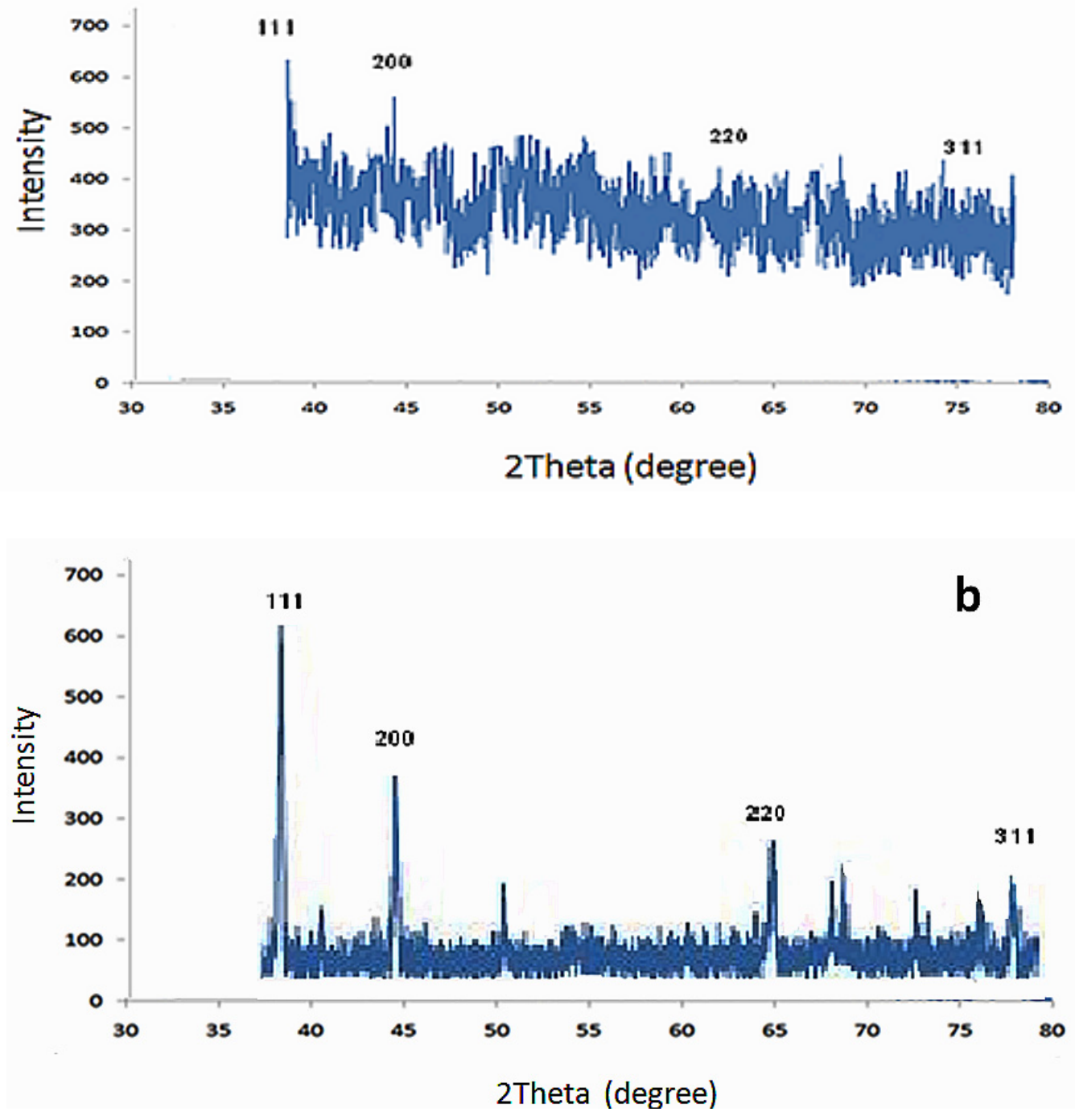

C

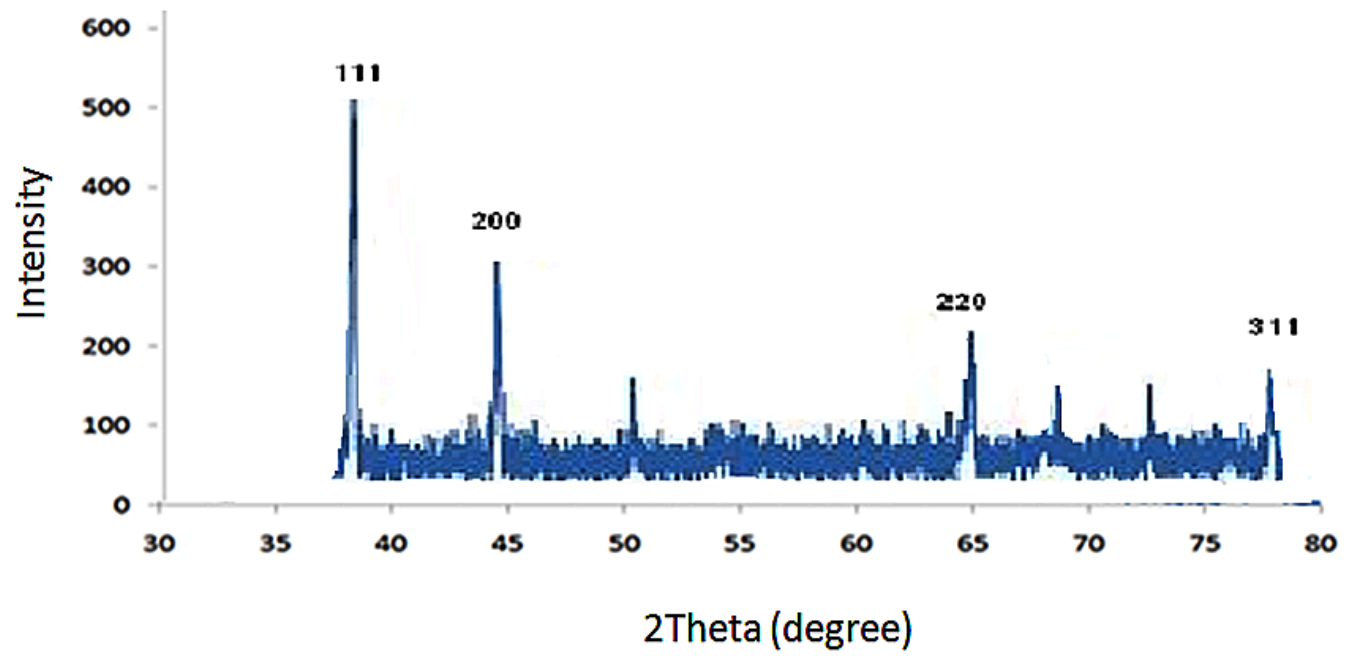


Figure 4. Cont.
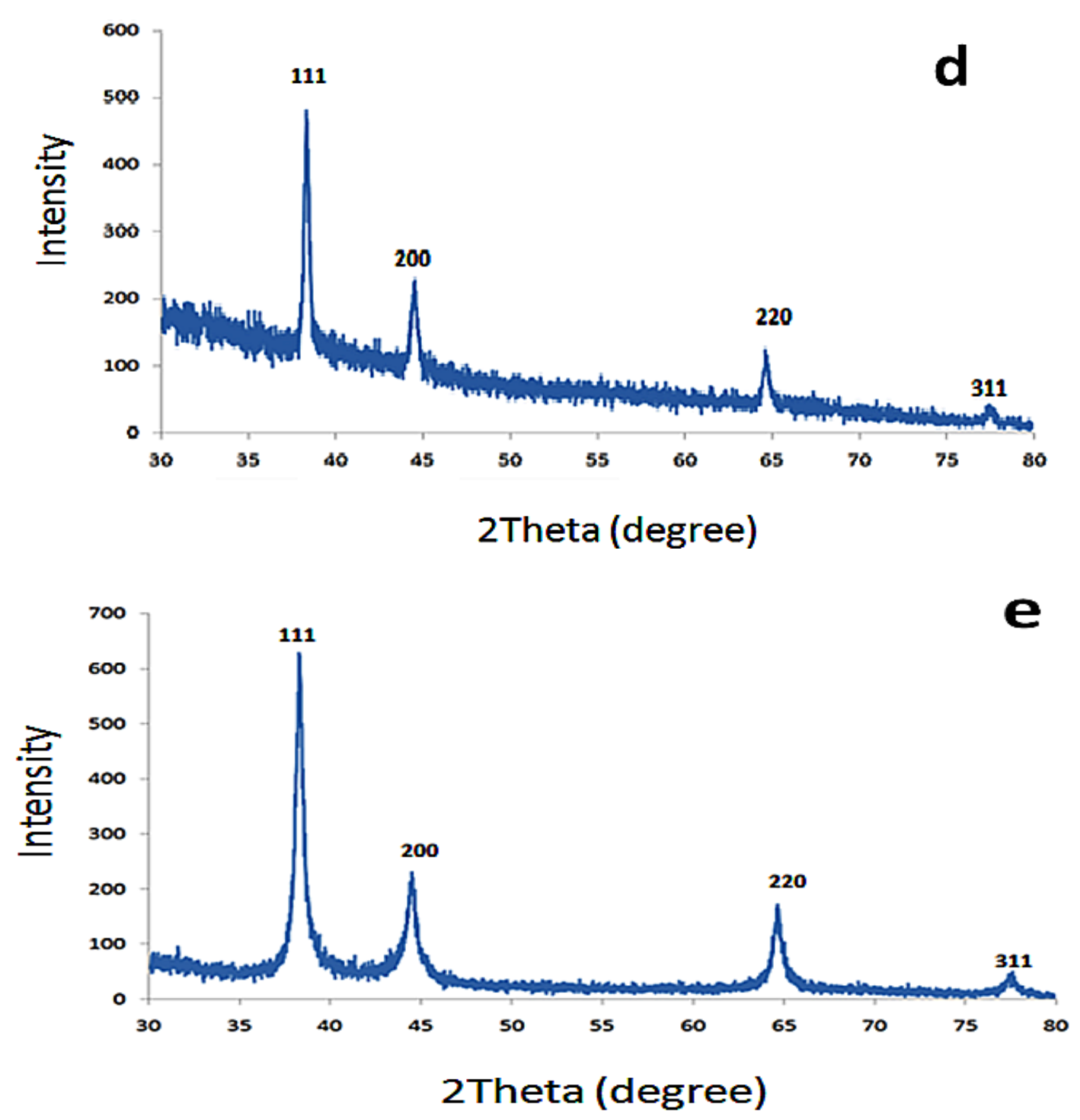

\subsection{Characteristics of Test Water Sources Before Treatment}

\subsubsection{Microbiological Quality of Test Water Sources}

Table 1 illustrates the initial concentrations of $E$. coli spiked in sterile synthetic water and groundwater with targeted bacteria before treatment. The initial count of the suspension for E. coli spiked in synthetic water was approximately $6 \log \mathrm{cfu} / 100 \mathrm{~mL}$. Therefore, after mixing thoroughly, the average count of $E$. coli was found to be $7 \log$ cfu/ $100 \mathrm{~mL}$. Initial presumptive $E$. coli in groundwater had an average count of $3 \log \mathrm{cfu} / 100 \mathrm{~mL}$. Salmonella typhimurium, S. dysenteriae and $V$. cholerae were not originally detected in the test groundwater samples. Consequently, these water source samples were spiked with initial concentrations of approximately $3 \log \mathrm{cfu} / 100 \mathrm{~mL}$ for each target organisms. However, after thoroughly mixing the spiked groundwater samples, the average counts for $S$. typhimurium, $S$. dysenteriae and $V$. cholerae as shown in Table 1 were approximately $3 \log \mathrm{cfu} / 100 \mathrm{~mL}$. 
Table 1. Microbiological quality of spiked water sources before treatment.

\begin{tabular}{ccccc}
\hline \multicolumn{5}{c}{ Bacterial concentrations (cfu/100 mL) before filtration } \\
\hline & \multicolumn{4}{c}{ Targeted organisms } \\
\cline { 2 - 5 } Water sources & Presumtive E. coli & S. typhimurium & S. dystenteriae & V. cholerae \\
\hline Synthetic water & $3.21 \times 10^{7}$ & $\mathrm{ND}$ & $\mathrm{ND}$ & $\mathrm{ND}$ \\
Groundwater & $3.15 \times 10^{3}$ & $1.20 \times 10^{3}$ & $2.71 \times 10^{3}$ & $2.01 \times 10^{3}$ \\
\hline ND-Not done. & & &
\end{tabular}

\subsubsection{Physicochemical and Microbiological Quality of Groundwater Source}

The characteristics of groundwater samples collected from a Delmas borehole (A7) are illustrated in Table 2. The average physicochemical values of groundwater were 7.22 for $\mathrm{pH} ; 1.59 \mathrm{NTU}$ for turbidity; $0.46 \mathrm{mg} / \mathrm{L}$ for fluorides; $1.59 \mathrm{mg} / \mathrm{L}$ for nitrates; $98.25 \mathrm{mg} / \mathrm{L}$ as Ca for calcium and $26.36 \mathrm{mg} / \mathrm{L}$ as $\mathrm{Mg}$ for magnesium, respectively. Regarding the microbiological quality, only presumptive E. coli (average count: $2.99 \times 10^{3} \mathrm{cfu} / 100 \mathrm{~mL}$ ) was present in groundwater samples.

Table 2. Characteristics of groundwater sample.

\begin{tabular}{cccc}
\hline Parameters & Units & Concentration & SANS 241 \\
\hline $\mathrm{pH}$ & - & $7.22 \pm 0.14$ & $5-9.5$ \\
Turbidity & $\mathrm{NTU}$ & $1.59 \pm 0.11$ & $<1$ \\
Fluorides & $\mathrm{mg} / \mathrm{L}$ & $0.46 \pm 0.18$ & $<1$ \\
Nitrates & $\mathrm{mg} / \mathrm{L}$ as N & $1.59 \pm 0.02$ & $<10$ \\
Calcium & $\mathrm{mg} / \mathrm{L}$ as Ca & $98.25 \pm 1.12$ & $<150$ \\
Magnesium & $\mathrm{mg} / \mathrm{L}$ as $\mathrm{Mg}$ & $26.36 \pm 7.18$ & $<70$ \\
E. coli & $\mathrm{cfu} / 100 \mathrm{~mL}$ & $2.99 \times 10^{3}$ & 0 \\
\hline
\end{tabular}

\subsection{Performance of Combined Substrates-Silver Nanoparticles in Removing Pathogenic Bacteria from} Synthetic Water

Figure 5 illustrates the effect of different concentrations of $\mathrm{AgNO}_{3}(0.01 \mathrm{mM}, 0.03 \mathrm{mM}, 0.05 \mathrm{mM}$ and $0.1 \mathrm{mM}$ ) deposited on substrates for the deactivation of E. coli. As seen in Figure 5(a), the filter system with uncoated zeolite (control) did not have any antibactericidal effect on E. coli. However, Ag/zeolite nanoparticle filter systems with $0.01 \mathrm{mM}$ and $0.03 \mathrm{mM}$ concentrations showed a $0.5 \mathrm{log} \mathrm{cfu} / 100 \mathrm{~mL}$ reduction of $E$. coli, while $0.05 \mathrm{mM}$ and $0.1 \mathrm{mM}$ concentrations showed a removal of $1.0 \log$ and $1.5 \log \mathrm{cfu} / 100 \mathrm{~mL}$ for the first $30 \mathrm{~min}$, respectively, and then an increase of bacterial counts resulting in a survival of more than $6 \log \mathrm{cfu} / 100 \mathrm{~mL}$ occurred in the filtered water after $90 \mathrm{~min}$ trial. The results showed a significant difference in the reduction of the $E$. coli count with $0.03 \mathrm{mM}$, $0.05 \mathrm{mM}$ and $0.1 \mathrm{mM}$ concentrations $(P<0.05)$, as compared to the control. 
Figure 5. Antibacterial activity of various Ag nanoparticle-coated substrates against $E$. coli at different concentrations in synthetic water: (a) zeolite, (b) sand, (c) fibreglass, (d) anion resin, and (e) cation resin.
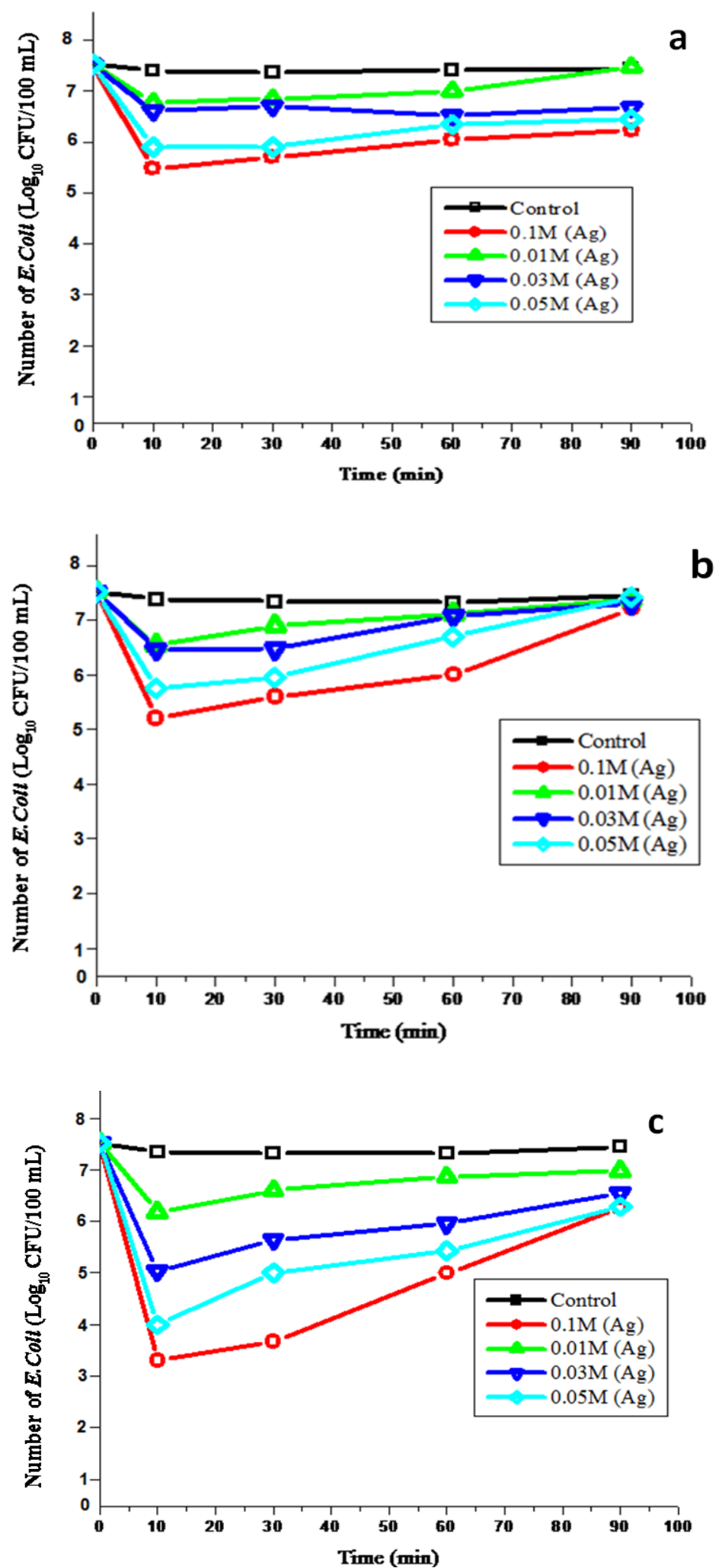
Figure 5. Cont.
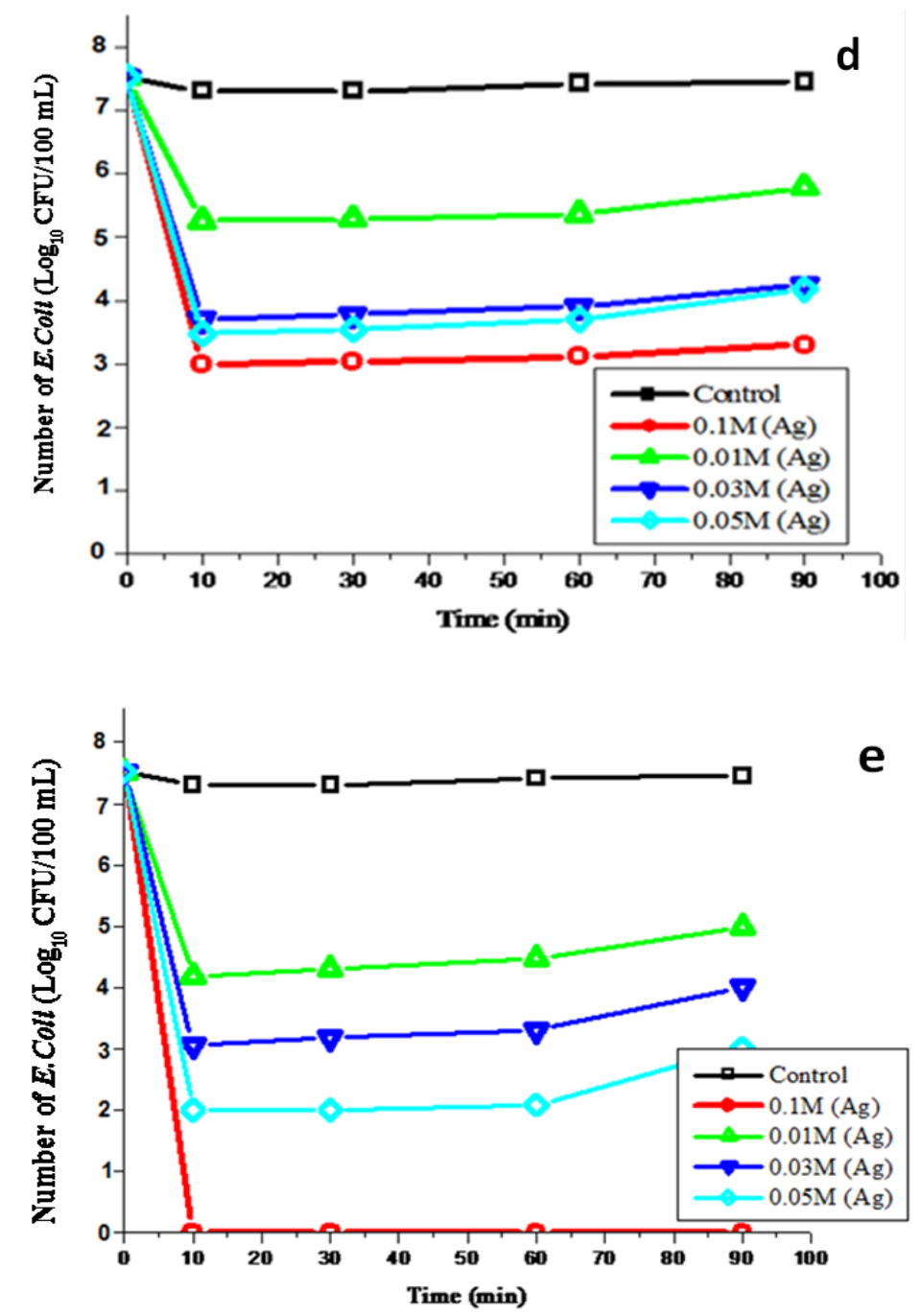

As shown in Figure 5(b), the uncoated sand (control) filter system did not have any antibacterial effect on E. coli. Filter systems with $\mathrm{Ag} / \mathrm{sand}$ nanoparticles reduced the $E$. coli count by $1.0 \log \mathrm{cfu} / 100 \mathrm{~mL}$ with a $0.01 \mathrm{mM}$ concentration in the first $10 \mathrm{~min}$ and with $0.03 \mathrm{mM}$ in the first 30 min and there was an increase in the $E$. coli count of more than $7 \log \mathrm{cfu} / 100 \mathrm{~mL}$ in the filtered water after $90 \mathrm{~min}$ trial. However, with $0.05 \mathrm{mM}$ and $0.1 \mathrm{mM}$ concentrations, a $2 \log$ and $2.5 \log \mathrm{cfu} / 100 \mathrm{~mL}$ reduction of the $E$. coli count was observed in the first $10 \mathrm{~min}$, and subsequently the $E$. coli counts increased again in filtered water. The results showed a significant difference in the reduction of the E. coli count with filters containing $0.03 \mathrm{mM}, 0.05 \mathrm{mM}$ and $0.1 \mathrm{mM}$ concentrations $(P<0.05)$, as compared to the control.

Figure 5(c) shows that no E. coli deactivation was observed with uncoated fibreglass (control). The filter systems with Ag/fibreglass nanoparticles indicated a reduction of $1.2 \log \mathrm{cfu} / 100 \mathrm{~mL}$ E. coli in the first 10 min with a $0.01 \mathrm{mM}$ concentration and $2.5 \log \mathrm{cfu} / 100 \mathrm{~mL}$ with a $0.03 \mathrm{mM}$ concentration during the same period. Thereafter, the growth of E. coli increased between 6 and $7 \mathrm{cfu} / 100 \mathrm{~mL}$ in the filtered water after $90 \mathrm{~min}$ trial. A high performance of the $\mathrm{Ag} /$ fibreglass nanoparticle filter system was observed when $0.05 \mathrm{mM}$ and $0.1 \mathrm{mM}$ concentrations were used. The results showed that $3.5 \log \mathrm{cfu} / 100 \mathrm{~mL}$ E. coli was removed within the first 10 min with a $0.05 \mathrm{mM}$ concentration and 
$4.3 \log \mathrm{cfu} / 100 \mathrm{~mL}$ within the first $30 \mathrm{~min}$ with a $0.1 \mathrm{mM}$ concentration, respectively. Thereafter, growth of $E$.coli in filtered water was noticed. There was a significant difference in the reduction of $E$. coli counts with these filter systems containing $0.03 \mathrm{mM}, 0.05 \mathrm{mM}$ and $0.1 \mathrm{mM}$ concentrations $(P<0.05)$, as compared to the control.

As illustrated in Figure 5(d), the uncoated anion resin (control) filter system did not have any antibacterial effect against $E$. coli. Filter systems with $\mathrm{Ag} /$ anion nanoparticles reduced the $E$. coli count by $2.0 \log \mathrm{cfu} / 100 \mathrm{~mL}$ with a $0.01 \mathrm{mM}$ concentration in the first $10 \mathrm{~min}$ and there was an increase in the $E$. coli count in the filtered water. However, with 0.03 and $0.05 \mathrm{mM}$ concentrations, a $4 \log \mathrm{cfu} / 100 \mathrm{~mL}$ reduction of $E$. coli count was observed in the first $60 \mathrm{~min}$, while with a $0.1 \mathrm{mM}$ concentration a $4.5 \log \mathrm{cfu} / 100 \mathrm{~mL}$ reduction of $E$. coli was also observed in the same period. Thereafter, the growth of $E$. coli increased between 3 and $5.6 \mathrm{cfu} / 100 \mathrm{~mL}$ in filtered water after $90 \mathrm{~min}$ trial. The results showed a significant difference in the reduction of the $E$. coli count with filters containing $0.03 \mathrm{mM}, 0.05 \mathrm{mM}$ and $0.1 \mathrm{mM}$ concentrations $(P<0.05)$, as compared to the control.

The results of $\mathrm{Ag} /$ cation resin filter systems and uncoated cation resin (control) are shown in Figure 5(e). The results indicate that the uncoated resin filter did not have any antibacterial activity against $E$. coli. The filter systems with $\mathrm{Ag} /$ cation resin reduced $E$. coli by $3.5,4.5$ and $5.5 \operatorname{logs} \mathrm{cfu} / 100 \mathrm{~mL}$ with $0.01 \mathrm{mM}, 0.03 \mathrm{mM}$ and $0.05 \mathrm{mM}$ concentrations in the first $60 \mathrm{~min}$ of the filter run, respectively. Thereafter, a growth of between 2.5 and $4.8 \mathrm{cfu} / 100 \mathrm{~mL}$ E. coli in filtered water was noticed after $90 \mathrm{~min}$ trial. A complete removal ( $>7 \log \mathrm{cfu} / 100 \mathrm{~mL})$ of E. coli was achieved with $0.1 \mathrm{mM}$ concentrations during the entire filter run (90 minutes) without a further regrowth in the treated water. There was a significant difference in the reduction of $E$. coli between filter systems containing $0.01 \mathrm{mM}, 0.03 \mathrm{mM}, 0.05 \mathrm{mM}$ and $0.1 \mathrm{mM}$ concentrations $(P<0.05)$, as compared to the control. However, the antibacterial efficiency of the substrates with different concentrations were found not be significantly different from one another $(P>0.05)$, except for the $0.1 \mathrm{mM}$ concentration of $\mathrm{Ag}$ /cation resin $(P<0.05)$.

\subsection{Performance of Combined Substrates-Silver $(0.1 \mathrm{mM})$ Nanoparticles in Removing Pathogenic} Bacteria from Groundwater

Silver nanoparticle-coated substrates with $0.1 \mathrm{mM} \mathrm{AgNO}_{3}$ were selected for further investigation because of their performance efficiency. In general, the bactericidal activity of Ag nanoparticle substrates depended on the individual microorganism. For this reason, the test was carried out with Ag nanoparticle substrates against four bacterial strains by using groundwater containing presumptive E. coli with $3 \log \mathrm{cfu} / 100 \mathrm{~mL}$ and seeded with $3 \log \mathrm{cfu} / \mathrm{mL}$ of $S$. typhimurium, S. dysenteriae and V. cholerae.

Figure 6 indicates the reduction of pathogenic bacteria in the treated water by five combined substrate-silver nanoparticle filter systems. The filter systems containing Ag/zeolite nanoparticles (Figure 6(a)) completely removed presumptive E. coli, S. typhimurium, S. dysenteriae and V. cholerae within the first 10 minutes of the filter run. Thereafter, these pathogenic bacteria reappeared in the treated water samples with counts ranging between 0.25 and $2 \log$ removal. There was no significant difference $(P>0.05)$ in the regrowth of these pathogenic bacteria, except for the regrowth of $E$. coli 
and $S$. typhimurium, where a significant difference $(P>0.05)$ was observed with the Ag/zeolite nanoparticle filter system in the treated water.

Figure 6. Antibacterial activity of various $\mathrm{Ag}$ nanoparticle substrates at $0.01 \mathrm{mM}$ concentration against E. coli, S. typhimurium, $S$. dysenteriae and $V$. cholerae in groundwater: (a) zeolite, (b) sand, (c) fibreglass, (d) anion resin, and (e) cation resin.
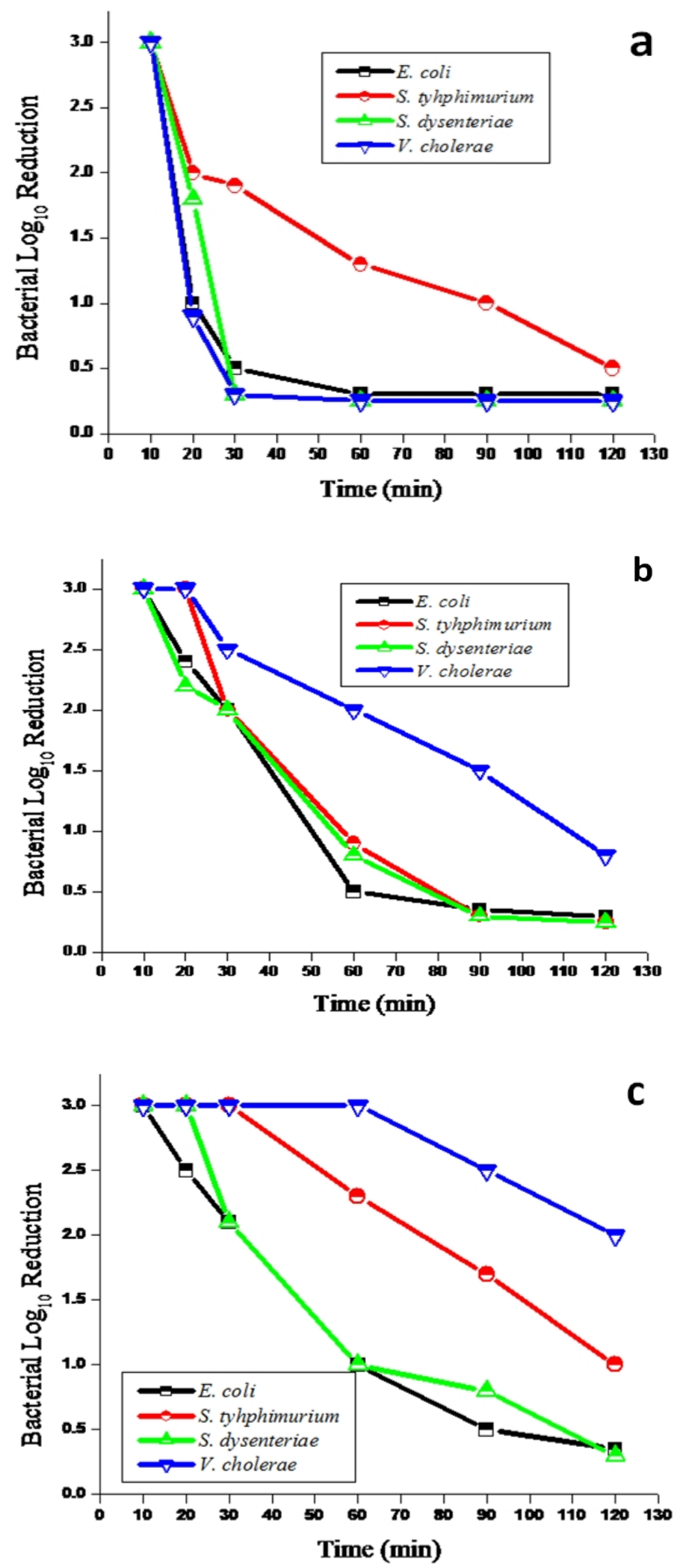
Figure 6. Cont.
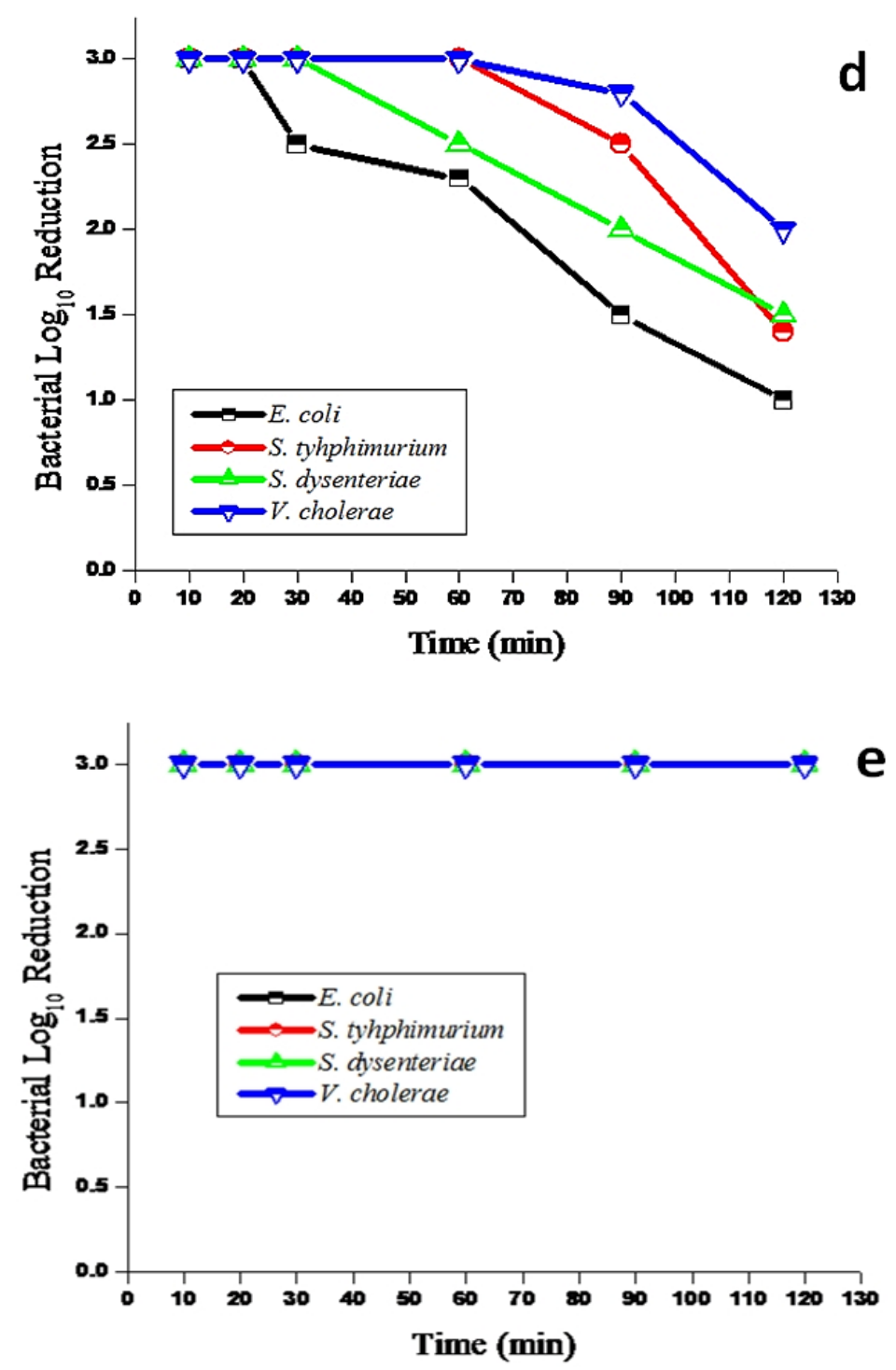

The combined sand-silver nanoparticles filter system (Figure 6(b)) showed a complete removal (3 $\log$ ) of presumptive E. coli and $S$. dysenteriae during the first $10 \mathrm{~min}$ of the filter run, while $S$. typhimurium and $V$. cholerae were completely removed within the first $20 \mathrm{~min}$. Thereafter, E. coli and $S$. dysenteriae reappeared in the treated water samples for the rest of the study period and their counts ranged between 0.25 and $2.4 \log$ cfu/100 mL, respectively. Salmonella typhimurium and $V$. cholerae reappeared in the treated water for the last $100 \mathrm{~min}$ of the filter run and their counts ranged between 0.25 and $2.5 \log \mathrm{cfu} / 100 \mathrm{~mL}$. There was no significant difference $(P>0.05)$ in the regrowth of these pathogenic bacteria with the $\mathrm{Ag} /$ sand nanoparticle filter system in the treated water.

The filter system with Ag/fibreglass nanoparticles (Figure 6(c)) completely removed (3 $\log \mathrm{cfu} /$ $100 \mathrm{~mL}$ ) presumptive E. coli in the first $10 \mathrm{~min}, S$. dysenteriae in the first $20 \mathrm{~min}$, S. typhimurium in the first $30 \mathrm{~min}$ and $V$. cholerae in the first $60 \mathrm{~min}$ of the filter run. Subsequently, they reappeared in the treated water for the remaining time of the filter run and their counts ranged between 0.3 and $2.5 \log \mathrm{cfu} / 100 \mathrm{~mL}$. There was no significant difference $(P>0.05)$ in the regrowth of E. coli, $S$. typhimurium and $S$. dysenteriae with the $\mathrm{Ag} /$ fibreglass nanoparticle filter system, except for $E$. coli and $V$. cholerae, where there was a significant difference $(P<0.05)$ in the treated water. 
The combined anion resin-silver nanoparticle filter system completely removed $3 \mathrm{log} \mathrm{cfu} / 100 \mathrm{~mL}$ of presumptive E. coli in the first $20 \mathrm{~min}, S$. dysenteriae in the first $30 \mathrm{~min}$, and $S$. typhimurium and $V$. cholerae in the first $60 \mathrm{~min}$ of the filter run. Subsequently, these organisms progressively reappeared in the treated water with counts ranging between 1 and $2.8 \log \mathrm{cfu} / 100 \mathrm{~mL}$. There was no significant difference $(P>0.05)$ in the regrowth of these pathogenic bacteria with the Ag/anion resin nanoparticle filter system in the treated water.

The use of the cation resin-silver nanoparticle filter system (Figure 6(e)) resulted in a complete removal $(3 \log \mathrm{cfu} / 100 \mathrm{~mL})$ of the target pathogenic bacteria and there was no bacterial regrowth during the entire $120 \mathrm{~min}$ of the filter run. Statistically, the performance of $\mathrm{Ag} / \mathrm{cation}$ resin nanoparticles in removing all targeted pathogenic bacteria from groundwater was found to be significantly higher compared to the other filters when considering the phenomenon of bacterial regrowth that characterised the latter filters.

\subsection{Elution of Silver Ions from Silver Nanoparticle Substrates}

Figure 7 shows the $\mathrm{Ag}^{+}$ions eluted from filter materials coated with silver nanoparticles. A high concentration of silver was eluted from Ag/zeolite, Ag/sand, Ag/fiberglass and Ag/anion resin substrates within the first 10 minutes of the filter run.

The content of silver released from these filters ranged between 1.0 and $1.8 \mathrm{mg} / \mathrm{L}$ for $0.1 \mathrm{mM} \mathrm{Ag}$, between 0.7 and $0.8 \mathrm{mg} / \mathrm{L}$ for $0.05 \mathrm{mM} \mathrm{Ag}$, between 0.5 and $0.6 \mathrm{mg} / \mathrm{L}$ for $0.03 \mathrm{mM} \mathrm{Ag}$, and between 0.1 and $0.2 \mathrm{mg} / \mathrm{L}$ for $0.01 \mathrm{mM} \mathrm{Ag}$. Consequently, after $90 \mathrm{~min}$ trial there was no silver ion detected in the filtered water from zeolite, sand fiberglass and anion resin substrates. However, the amount of the silver released from the $\mathrm{Ag} /$ cation resin was below $0.1 \mathrm{mg} / \mathrm{L}$ for all four the different concentrations investigated during the study period.

Figure 7. Amount of silver eluted from Ag nanoparticle-coated substrates in synthetic water: (a) zeolite, (b) sand, (c) fiberglass, (d) anion resin, and (e) cation resin.

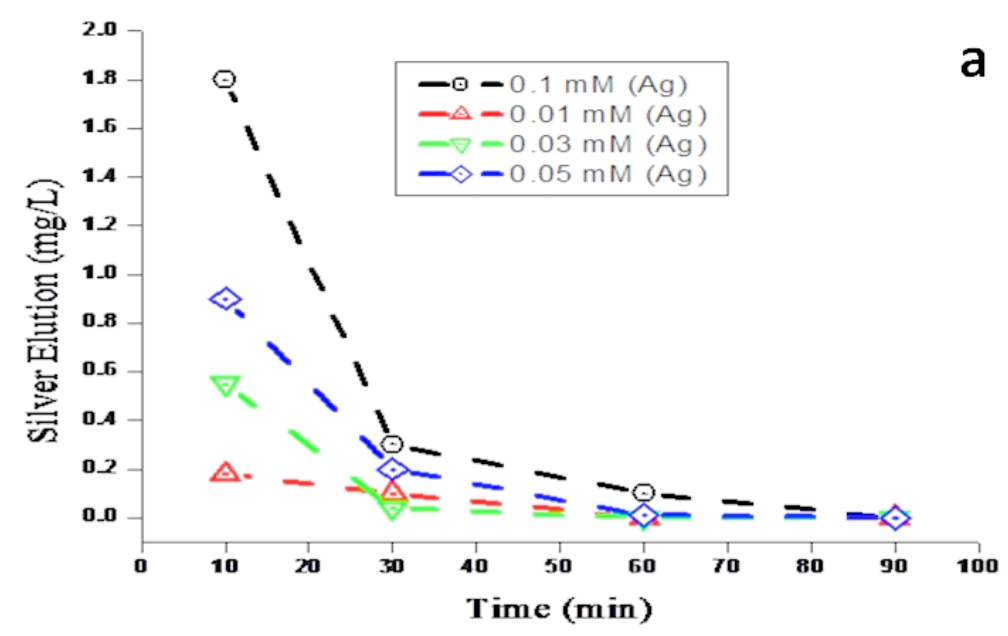


Figure 7. Cont.
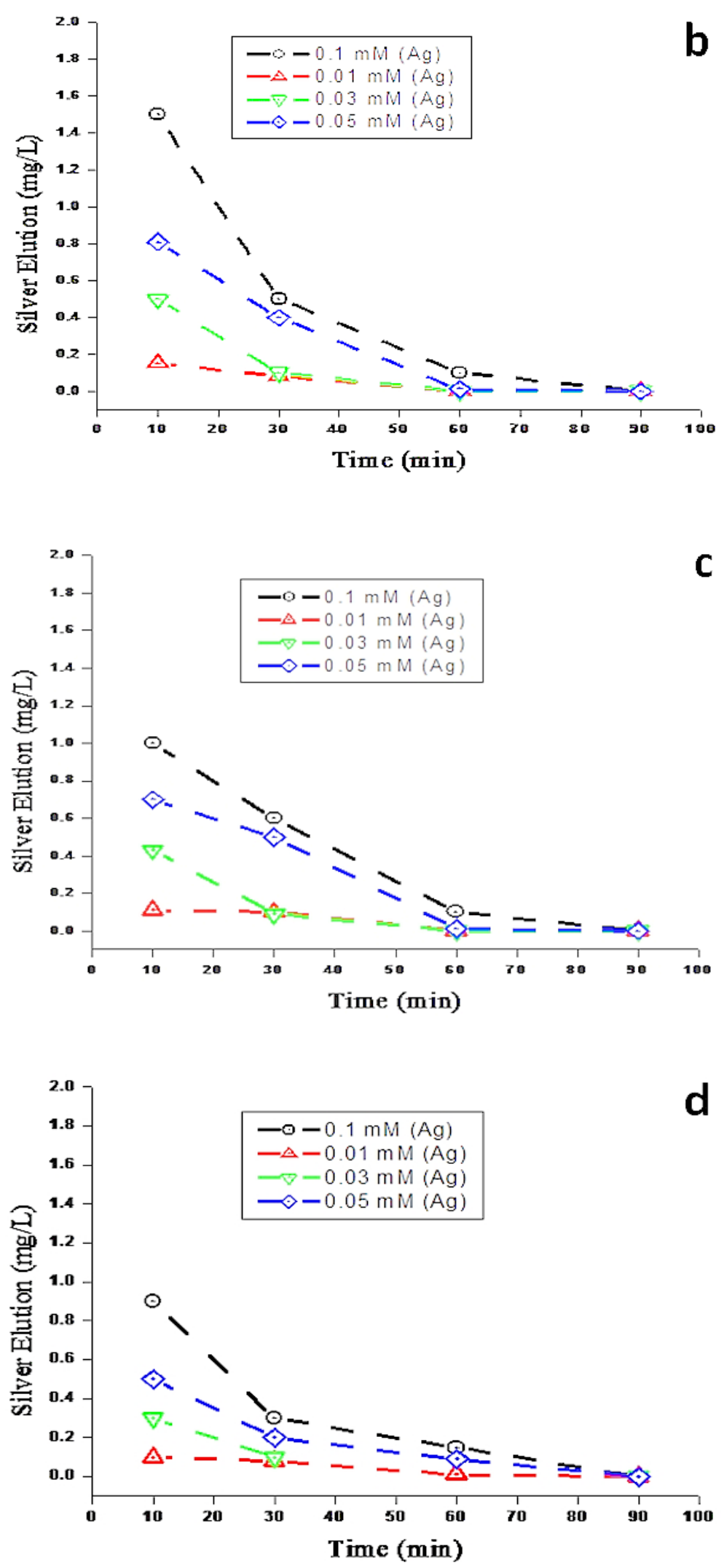
Figure 7. Cont.

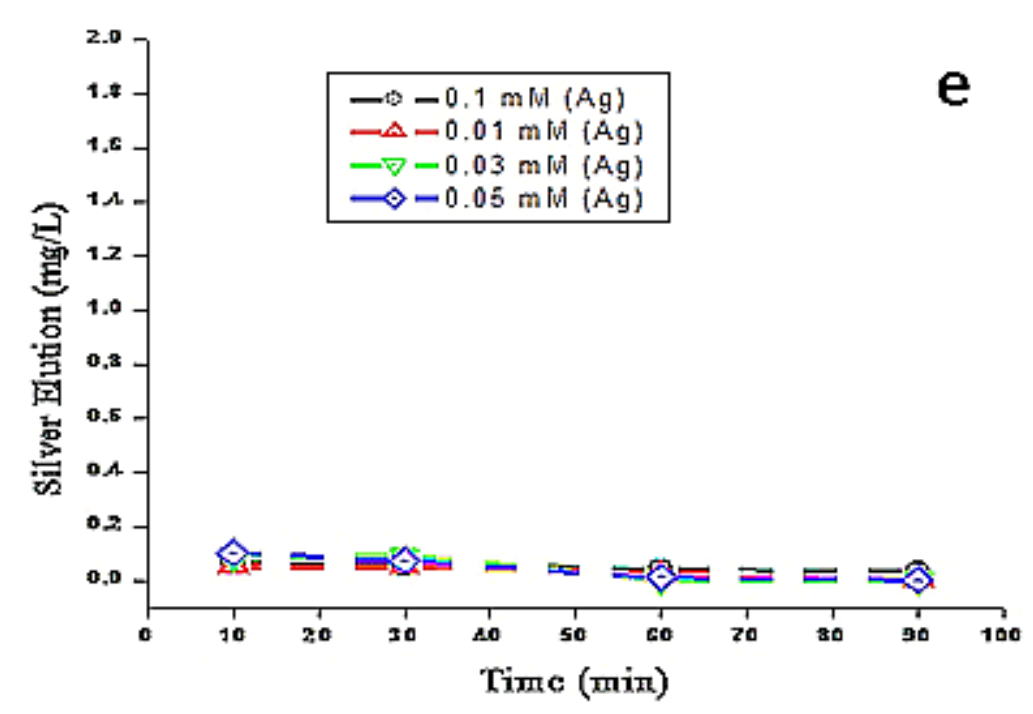

\section{Discussion}

The increasing demand for access to safe drinking water and the problems associated with centralised systems in developing countries have made decentralised systems vital for the development of new technologies to address these challenges, especially in scattered communities depending totally on groundwater supplies. Therefore, this study explored the use of nanosized silver impregnated onto cost-effective materials locally available in South Africa for possible use in drinking water disinfection. Using hydrothermal and chemical methods, it was revealed that silver nanoparticles were successfully deposited onto sand, zeolite, fibreglass, anion and cation resin substrates. However, in the case of the silver coatings, the antibacterial effect was found to reduce with time and the coatings had minimal antibacterial properties at $30 \mathrm{~min}$. The ion elution studies (Figure 7) indicated that between 60 and $90 \%$ of silver loaded on the $\mathrm{Ag} / \mathrm{zeolite}, \mathrm{Ag} / \mathrm{sand}, \mathrm{Ag} /$ fibreglass and $\mathrm{Ag} /$ anion resin substrates eluted into the treated samples. Consequently the low level of Ag ions remaining in the surface substrates after 30 min elution is responsible for the decrease of bacterial removal at this time point. It was also discovered by [38] that silver eluted into water when using Ag-zeolite. The elution of silver from the substrates might be due to the weak attachment of silver nanoparticles to the surface substrates. High concentrations of silver ions eluted in water can be toxic to human cells and potentially cause adverse effects in the case of long-term implants. The amount of silver ions eluted from $\mathrm{Ag} /$ zeolite, $\mathrm{Ag} / \mathrm{sand}, \mathrm{Ag} /$ fibreglass and $\mathrm{Ag} /$ anion resin exceeded by far the recommended limit set by the World Health Organisation and US Environmental Protection Agency (USEPA), which is less than $0.10 \mathrm{mg} / 1$ in drinking water used for human consumption. The amount of silver ions eluted from $\mathrm{Ag} /$ cation resin complied with the WHO and USEPA limits [39,40]. Conversely, the high levels of ions (95\%) still present in the $\mathrm{Ag} /$ cation resin surface after 30 min would explain the retention of the antimicrobial properties of that surface over the $90 \mathrm{~min}$ of the trial. Scanning electron microsope images revealed that the Ag nanoparticles on the substrates were predominantly small and spherical with EDS confirming the presences of silver peaks, as shown in Figure 2. The TEM images also revealed spherical-shaped particles that aggregated to each other on the silver nanoparticle substrates, which indicated a particle size distribution ranging between 5 and $90 \mathrm{~nm}$. This result was in 
accordance with the results obtained from the XRD pattern lattice measurement corresponding to the (111) silver plane (Figure 4). The crystalline nature of Ag nanoparticles was confirmed by the XRD experimental study. The diffraction pattern observed from the XRD matches the face-centered cubic (fcc) structure of silver as described by previous investigators [41,42]. It was reported by [33] that the two broad reflection peaks corresponding to (111) and (200) planes indicate that the silver particles are nanocrystals with cubic symmetry. A similar observation was reported by [43]. According to these authors, both the nanoscale size and the presence of a (111) plane of Ag nanoparticles promote the biocidal property of $E$. coli $[33,43]$.

The physicochemical analyses of the tested groundwater source were within the recommended limits of no risk for drinking except for turbidity which was above the SANS 241 limit [35]. High turbidity levels are associated with poor water quality and promote the survival of microorganisms [36]. Turbidity can also protect microorganisms from the effects of disinfection, stimulate the growth of bacteria and give rise to a significant disinfection demand [42].

Escherichia coli was found to be present at the highest concentration of $3 \log \mathrm{cfu} / 100 \mathrm{~mL}$ in groundwater samples collected from Delmas, while the limit recommended by SANS 241 is $0 \mathrm{cfu} /$ $100 \mathrm{~mL}$ for drinking water that is meant for human consumption. Although S. typhimurium, $S$. dysenteriae and $V$. cholerae were not detected in the groundwater samples, these pathogenic bacteria were seeded into the groundwater samples at a concentration of approximately $3 \log \mathrm{cfu} / 100 \mathrm{~mL}$ in order to determine the removal efficiency of the filters. In the first part of this study, the antibacterial efficiency of the combined substrates-silver nanoparticle filter systems were determined, using various concentrations of silver nitrate against $E$. coli as the test organism. The aim of this part of the study was to determine the concentration of silver that would have the most effective antibacterial property against the E. coli. The results indicated that all the filter systems containing uncoated substrates (Figure 5(a-e)) were unable to deactivate $E$. coli from synthetic water when compared to the combined substrates-silver nanoparticles filter systems. The bactericidal effect of silver nanoparticle substrates depended on the concentrations of the silver nitrate as well as on the type of substrates. The higher the concentration of Ag added to modify the substrates, the greater was the removal of E. coli. In analyses regarding the effect of silver nanoparticles in a size range of 5-90 nm, significant reductions in the E. coli population were noted when using filter materials coated with $0.01 \mathrm{mM}, 0.03 \mathrm{mM}, 0.05 \mathrm{mM}$ and $0.1 \mathrm{mM}$ silver concentrations as compared to the control $(P<0.05)$. The overall results indicated a significantly higher bactericidal efficiency with $0.1 \mathrm{mM} \mathrm{AgNO}_{3}(P<0.05)$ compared to other silver concentrations, despite the phenomenon of bacterial regrowth that resulted in a progressive increase of bacterial counts in the treated water during the subsequent operation of all the filters, except for the $\mathrm{Ag} /$ cation resin filter (Figure 5(a-e)). This filter showed the best performance, which resulted in the complete removal of $E$. coli from synthetic water without the occurrence of bacterial regrowth when the cation resin was loaded with $0.1 \mathrm{mM}$ silver (Figure 5(e)). The particle sizes of silver ranging between 1 and $100 \mathrm{~nm}$ have been reported to have an effect on the antibacterial properties of nanoparticles [14]. Silver nanoparticles cause irreversible damage to the cellular membrane $[18,43,44]$, which enables the accumulation of nanoparticles in the cytoplasm. The action of silver nanoparticles is due to this damage and not to its toxicity [45]. Previous investigators have pointed out that $\mathrm{Ag}$ nanoparticles bind to the outer membrane of E. coli, causing the inhibition of active transport, dehydrogenase and periplasmic enzyme activity and eventually the inhibition of RNA, DNA and a 
decrease in the cell permeability, which finally results in cell lysis [18,45-47]. While microorganisms carry a negative charge, the Ag ions carry a positive charge, which is crucial for its antimicrobial activity through the electrostatic attraction between the negatively charged cell membrane of microorganisms and positively charged nanoparticles [48-50]. [51,52] indicated that the higher the concentration, the better the antibacterial activity will be. The percentage removal of $E$. coli from synthetic water was also in accordance with findings by previous investigations using a silver-coated ceramic water filter and silver-coated cylindrical polypropylene filters [53,54].

In the second part of the study, the antibacterial activities of combined substrates-silver nanoparticle filter systems prepared from $0.1 \mathrm{mM} \mathrm{AgNO}_{3}$ were investigated against E. coli, S. typhimurium, $S$. dysenteriae and $V$. cholerae found or spiked in groundwater samples. The results of this part of the study also showed a decrease in bacterial concentrations from groundwater samples by all filters (Figure 6). While the regrowth of targeted pathogenic bacteria occurred in water treated by Ag/zeolite, $\mathrm{Ag} / \mathrm{sand}, \mathrm{Ag} /$ fibreglass and $\mathrm{Ag} /$ anion resin, this phenomenon did not occur in drinking water treated with the $\mathrm{Ag} /$ cation resin nanoparticle filter system. This filter produced drinking water that complied with the limit of $E$. coli $0 \mathrm{cfu} / 100 \mathrm{~mL}$ as set by the South African guidelines [35,36]. The silver cation resin nanoparticle filter system achieved a 100\% removal of all the targeted pathogenic bacteria during the entire $120 \mathrm{~min}$ of the filter operation. This performance of the Ag/cation resin nanoparticle filter system, namely removing $100 \%$ E. coli, was also reported by other researchers who used silver nanoparticle filters $[55,56]$. The results achieved in the first $10 \mathrm{~min}$ of the filter operation with a $\mathrm{Ag} /$ fibreglass nanoparticle filter system in removing E. coli confirmed those reported by [23] when these authors used a similar filter system for the purification of drinking water. Taking into account the performance of resin-silver nanoparticle filters in removing pathogenic bacteria and their level of silver ion elution in the drinking water, this suggests the use of this type of filter system as an alternative decentralisation technology for the production of safe drinking water for communities depending on groundwater supplies.

\section{Conclusions and Recommendations}

Silver nanoparticle-coated substrates were prepared successfully by the chemical reduction and hydrothermal synthesis method. Detailed characterisation of the nanoparticles was carried out using SEM, EDS, TEM, Particle Size Distribution and XRD analyses, which confirmed the presences of silver loading on the substrates. The performance of the substrates as antibacterial water filter system was checked and no bacterium was detected in the output water when the $\mathrm{Ag} /$ cation resin substrate was used as a filter system. Low bacterial removal by $\mathrm{Ag} / \mathrm{zeolite}, \mathrm{Ag} / \mathrm{sand}, \mathrm{Ag} /$ fibrelass and $\mathrm{Ag}$ /anion resin filter systems was observed, which led to the conclusion that these systems are not ideal systems for the disinfection of drinking water. Consequently, a combined cation-resin silver nanoparticle system is the sole drinking-water purification system suggested by this study. This technology can offer complete anti-microbial solutions to rural communities. Further studies will be conducted on the lifespan of the combined cation-resin silver nanoparticle filter system and the communities will be informed of the period for which they can use this filter system 


\section{Acknowledgements}

We thank the National Research Foundation (NRF) of South Africa and the Tshwane University of Technology for funding this study.

\section{Conflict of Interest}

The authors declare no conflict of interest.

\section{References}

1. World Health Organization (WHO). Water, Sanitation and Hygiene Links to Health; WHO: Geneva, Switzerland, 2004.

2. Momba, M.N.B.; Kaleni, P. Regrowth and survival of indicator microorganisms on the surfaces of household containers used for the storage of drinking water in rural communities of South Africa. Water Res. 2002, 36, 3023-3028.

3. Edberg, S.C.; Rice, E.W.; Karlin, R.J.; Allen, M.J. Escherichia coli: The best biological drinking water indicator for public health protection. Symp. Ser. Sco. Appl. Microbiol. 2000, 88, S106-S116.

4. Enriquez, C.; Nwachuku, N.; Gerba, C.P. Direct exposure to animal enteric pathogens. Rev. Environ. Health 2001, 16, 117-131.

5. Momba, M.N.B.; Notshe, T.L. The microbiological quality of groundwater-derived drinking water after long storage in household containers in a rural community of South Africa. J. Water Sup. Res. Tech. 2003, 52, 67-77.

6. Momba, M.N.B.; Malakate, V.K.; Theron, J. Abundance of phathogenic Escherichia coli, Salmonella typhimurium and Vibrio cholerae in Nkonkobe drinking water sources. J. Water Health 2006, 4, 289-296.

7. WHO and UNICEF. Progress on Sanitation and Drinking-Water; World Health Organization and United Nations Children's Fund: Geneva, Switzerland, 2010.

8. Statistics South Africa. Millennium Development Goals Country Report. Republic of South Africa. 2010. Available online: http://www.statssa.gov.za/news_archive/Docs/MDGR_2010.pdf. (accessed on 18 September 2011).

9. Klasen, H.J. A historical review of the use of silver in the treatment of burns. II. Renewed interest for silver. J. Burns 2000, 26, 131-138.

10. Bosetti, M.; Masse, A.; Tobin, E.; Cannas, M. Silver coated materials for external fixation devices: In vitro biocompatibility and genotoxicity. Biomaterials 2002, 23, 887-892.

11. Richard, J.W.; Spencer, B.A.; McCoy, L.F.; Carina, E.; Washington, J. Edgar, P. Acticoat versus silverlon: The truth. J. Burns Surg. Wound Care 2002, 1, 11-20.

12. Niven, R. Investigation of Silver Electrochemistry Water Disinfection Application. M.S. Thesis, McGill University: Montreal, QC, Canada, 2005.

13. Ovington, L.G. The truth about silver. Ostomy Wound Manage 2004, 50, S1-S10.

14. Rai, M.; Yadav, A.; Gade, A. Silver nanoparticles as a new generation of antimicrobials. Biotech. Adv. 2009, 27, 76-83. 
15. Kumar, A.; Vemula, P.K.; Ajayan, P.M.; John, G. Silver-nanoparticle-embedded antimicrobial paints based on vegetable oil. Nat. Mater. 2008, 7, 236-241.

16. Duran, N.; Marcato, P.D.; De Conti, R.; Alves, O.L.; Costa, F.T.M.; Brocchi, M. Potential use of silver nanoparticles on pathogenic bacteria, their toxicity and possible mechanisms of action. J. Brazil Chem. Soc. 2010, 21, 949-959.

17. Matsumura, Y.; Yoshikata, K.; Kunisaki, S.I.; Tsuchido, T. Mode of bactericidal action of silver zeolite and its comparison with that of silver nitrate. Appl. Environ. Microbiol. 2003, 69, 4278-4281.

18. Sondi, I.; Salopek-Sondi, B. Silver nanoparticles as antimicrobial agent: A case study on E. coli as a model for Gram-negative bacteria. J. Colloid Interface Sci. 2004, 275, 177-182.

19. Stoimenov, P.K.; Klinger, R.L.; Marchin, G.L.; Klabunde, K.J. Metal oxide nanoparticles as antibacterial agents. Langmuir 2002, 18, 6679-6686.

20. Cho, K.H.; Park, J.E.; Osaka, T.; Park, S.G. The study of antimicrobial activity and preservative effects of nanosilver ingredient. Electrochim. Acta 2005, 51, 956-960.

21. Jain, P.; Pradeep, T. Potential of silver nanoparticle-coated polyurethane form as an antibacterial water filter. Biotechnol. Bioeng. 2005, 90, 59-63.

22. Nair, A.S.; Pradeep, T. Extraction of chlorpyrifos and malathion from water by metal nanoparticles. J. Nanosci. Nanotechnol. 2007, 7, 1871-1877.

23. Mahmood, S.N.; Naeem. S.; Basit, N.; Usmani, T.H. Microbial evaluation of silver coated/ impregnated sand for purification of contaminated water. Environ. Technol. 1993, 14, 151-157.

24. Nangmenyi, G.; Yue, Z.; Mehrabi, S.; Mintz, E.; Economy, J. Synthesis and characterization of Ag nanoparticle impregnated fiberglass and utility in water disinfection. Nanotechnology 2009, 20, 495-505.

25. Logsdon, G.S.; Kohne, R.; Abel, A.; LaBonde, S. Slow sand filtration for small water systems. J. Environ. Eng. Sci. 2002, 1, 339-348.

26. Rivera-Garza, M.; Olguín, M.T.; García-Sosa, I.; Alcántara, D.; Rodríguez-Fuentes, G. Silver supported on natural Mexican zeolite as an antibacterial material. Micropor. Mesopor. Mat. 2000, 39, 431-444.

27. Top, A.; Ülkü, S. Silver, zinc, and copper exchange in a naclinoptilolite and resulting effect on antibacterial activity. Appl. Clay Sci. 2004, 27, 13-19.

28. Sheet Metal and Air Conditioning Contractors' National Association (SMACNA). Current Safety and Health Issues in Fiberglass; SMACNA: Chantilly, VA, USA, 1997; pp. 2903-2980.

29. Bürgers, R.; Eidt, A.; Frankenberger, R.; Rosentritt, M.; Schweikl, H.; Handel, G.; Hahnel, S. The anti-adherence activity and bactericidal effect of microparticulate silver additives in composite resin materials. Arch. Oral Biol. 2009, 54, 595-601.

30. Fan, C.; Chu, L.; Rawls, H.R.; Norling, B.K.; Cardenas, H.L.; Whang, K. Development of an antimicrobial resin-A pilot study. Dent. Mater. 2011, 27, 322-328.

31. Purolite International Ltd. Purolite Ion Exchange Resins; Purolite International Ltd.: Bala Cynwyd, PA, USA.

32. Rohm and Haas. Ion Exchange Introduction; Lenntech BV: Delft, The Netherlands, 2008. Available online: http://www.lenntech.com/Data-sheets/Ion-Exchange-for-Dummies-RH.pdf. (accessed on 3 October 2011). 
33. Jana, S.; Ghosh, S.K.; Nath, S.; Pande, S.; Praharaj, S.; Panigrahi, S.; Basu, S.; Endo, T.; Pal, T. Synthesis of silver nanoshell-coated cationic polystyrene beads: A solid phase catalyst for the reduction of 4-nitrophenol. Appl. Catal. A Gen. 2006, 313, 41-48.

34. Nath, S.; Ghosh, S.K.; Kundu, S.; Praharaj, S.; Panigrahi, S.; Basu, S.; Pal, T. A convenient approach to synthesize silver nanoshell covered functionalized polystyrene beads: A substrate for surface enhanced Raman scattering. Mater. Lett. 2005, 59, 3986-3989.

35. SANS 241. South African National Standard: Drinking water; Standards South Africa: Pretoria, South Africa, 2006.

36. Department of Water Affairs and Forestry (DWAF). South African Water Quality Guidelines. Vol 1: Domestic Use, 2nd ed.; DWAF: Pretoria, South Africa, 1996.

37. American Public Health Association (APHA). Standard Methods for Examination of Water and Wastewater, 20th ed; APHA: Washington, DC, USA, 1998.

38. Inoue, Y.; Hoshino, M.; Takahashi, H.; Noguchi, T.; Murata, T.; Kanzaki, Y.; Hamashima, H.; Sasatsu, M. Bactericidal activity of Ag-zeolite mediated by reactive oxygen species under aerated conditions. J. Inorg. Biochem. 2002, 92, 37-42.

39. World Health Organization (WHO). Guidelines for Drinking-Water Quality, 3rd ed.; WHO: Geneva. Switzerland, 2006; Volume 1.

40. United States Environmental Protection Agency (USEPA). Edition of the Drinking Water Standards and Health Advisories; EPA 822-R-06-013; Office of Water U.S. Environmental Protection Agency: Washington, DC, USA, 2006.

41. Dong, A.G.; Wang, Y.J.; Tang, Y.; Ren, N.; Yang, W.L.; Gao, Z. Fabrication of compact silver nanoshells on polystyrene spheres through electrostatic attraction. Chem. Commun. 2002, 4, 350-351.

42. Jiang, G.H.; Wang, L.; Chen, T.; Yu, H.J.; Wang, J.J. Preparation and characterization of dendritic silver nanoparticles. J. Mat. Sci. 2005, 40, 1681-1683.

43. Pal, S.; Tak, Y.K.; Song, J.M. Does the antibacterial activity of silver nanoparticles depend on the shape of the nanoparticle? A study of the gram-negative bacterium Escherichia coli. Appl. Environ. Microbiol. 2007, 73, 1712-1720.

44. Gorgoi, S.K.; Gopinanth, P.; Paul, A.; Ramesh, A.; Ghosh, S.S.; Chattopadhyay, A. Green fluorescent protein-expressing Escherichia coli as a model system for investigating the antimicrobial activities of silver nanoparticles. Langmuir 2006, 22, 9322-9328.

45. Russell, A.D.; Hugo, W.B. Antimicrobial activity and action of silver. Prog. Med. Chem. 1994, 31, 351-370.

46. Morones, J.R.; Elechiguerra, J.L.; Camacho, A.; Holt, K.; Kouri, J.B.; Ramirez, J.T.; Yacaman, M.J. The bactericidal effect of silver nanoparticles. Nanotechnology 2005, 16, 2346-2353.

47. Zhang, $\mathrm{H}$; Chen, G. Potent antibacterial activities of $\mathrm{Ag} / \mathrm{TiO}_{2}$ nanocomposite powders synthesized by a one-pot sol-gel method. Environ. Sci. Technol. 2009, 43, 2905-2910.

48. Dragieva, I.; Stoeva, S.; Stoimenov, P.; Pavlikianov, E.; Klabunde, K. Complex formation in solutions for chemical synthesis of nanoscaled particles prepared by borohydride reduction process. Nanostruct. Mater. 1999, 12, 267-270. 
49. Hamouda, T.; Myc, A.; Donovan, B.; Shih, A.; Reuter, J.D.; Baker, J.R. A novel surfactant nanoemulsion with a unique non-irritant topical antimicrobial activity against bacteria, enveloped viruses and fungi. Microbiol. Res. 2000, 156, 1-7.

50. Dibrov, P.; Dzioba, J.; Gosink, K.K.; H7se CC. Chemiosmotic mechanism of antimicrobial activity of $\mathrm{Ag}(+)$ in Vibrio cholerae. Antimicrob. Agents Chemother. 2002, 46, 2668-2670.

51. Yamamoto, O.; Sawai, J.; Sasamoto, T. Change in antibacterial characteristics with doping amount of ZnO. Inter. J. Inorg. Mater. 2000, 2, 451-454.

52. Jung, W.K.; Koo, H.C.; Kim, K.W.; Shin, S.; Kim, S.H.; Park, Y.H. Antibacterial activity and mechanism action of the silver ion in Staphylococcus aureus and Escherichia coli. Appl. Environ. Microbiol. 2008, 74, 2171-2178.

53. Oyanedel, C.V.A.; Smith, J.A. Sustainable colloidal silver impregnated ceramic filter for point-ofuse water treatment. Environ. Sci. Technol. 2008, 42, 927-933.

54. Heidarpour, F.; Wan Ab Karim Ghani, W.; Fakhru'l-Razi, A.; Sobri, S.; Heydarpour, V.; Zargar, M.; Mozafari, M. Complete removal of pathogenic bacteria from drinking water using nano silver-coated cylindrical polypropylene filters. Clean Technol. Environ. Pol. 2010, 13, 1-9.

55. Phong, N.T.P.; Thanh, N.V.K.; Phuong, P.H. Fabrication of antibacterial water filter by coating silver nanoparticles on flexible polyurethane foams. J. Phys. 2009, 187, doi:10.1088/17426596/198/1/012079.

56. Heidarpour, F.; Ghani, W.A.W.A.K.; Fakhru'L-Razi, A.; Sobri, S.; Torabian, A.; Heydarpour, V.; Zargar, M. New trends in microbiological water treatment. DJNB 2011, 6, 791-802.

(C) 2012 by the authors; licensee MDPI, Basel, Switzerland. This article is an open access article distributed under the terms and conditions of the Creative Commons Attribution license (http://creativecommons.org/licenses/by/3.0/). 